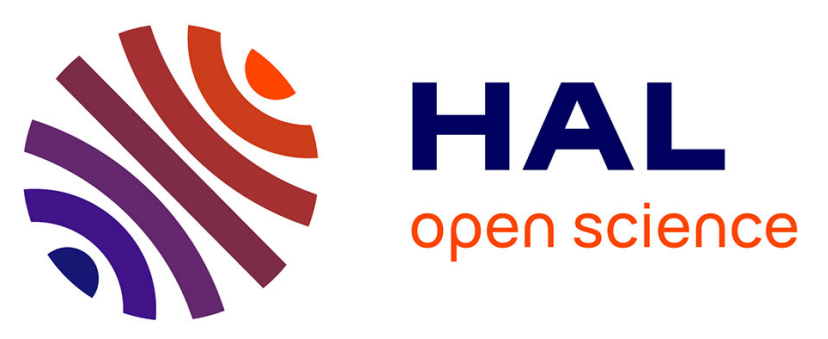

\title{
The impact of the hydrodechlorination process on the physicochemical properties of bimetallic Ag-CuBeta zeolite catalysts
}

A. Śrębowata, Izabela I. Kamińska, S. Casale, D. Brouri, C. Calers, Stanislaw Dzwigaj

\section{To cite this version:}

A. Śrębowata, Izabela I. Kamińska, S. Casale, D. Brouri, C. Calers, et al.. The impact of the hydrodechlorination process on the physicochemical properties of bimetallic Ag-CuBeta zeolite catalysts. Microporous and Mesoporous Materials, 2017, 243, pp.56-64. 10.1016/j.micromeso.2016.12.022 . hal01469231

\section{HAL Id: hal-01469231 \\ https: / hal.sorbonne-universite.fr/hal-01469231}

Submitted on 16 Feb 2017

HAL is a multi-disciplinary open access archive for the deposit and dissemination of scientific research documents, whether they are published or not. The documents may come from teaching and research institutions in France or abroad, or from public or private research centers.
L'archive ouverte pluridisciplinaire HAL, est destinée au dépôt et à la diffusion de documents scientifiques de niveau recherche, publiés ou non, émanant des établissements d'enseignement et de recherche français ou étrangers, des laboratoires publics ou privés. 


\section{The impact of the hydrodechlorination process on the physicochemical} properties of bimetallic Ag-CuBeta zeolite catalysts
A. Śrębowata ${ }^{1, *}$, Izabela I. Kamińska ${ }^{1}$, S. Casale ${ }^{2}$, D. Brouri ${ }^{2}$, C. Calers ${ }^{2}$, S. Dzwigaj $^{2, *}$
${ }^{1}$ Institute of Physical Chemistry, Polish Academy of Sciences, Kasprzaka 44/52, 01-224
Warsaw, Poland
${ }^{2}$ Sorbonne Universités, UPMC Univ Paris 06, CNRS, UMR 7197, Laboratoire de Réactivité de Surface, 4 place Jussieu, F-75252, Paris, France

Figures: 13

\section{*Corresponding authors}

Anna Srebowata, E-mail: $\quad$ asrebowata@ichf.edu.pl, $\quad$ Tel. 48223433320

Stanislaw Dzwigaj, E-mail : stanislaw.dzwigaj@upmc.fr, Fax : 33144272113 


\section{Abstract}

Beta zeolites with two Si/Al ratios of 17 and 1300 were used for synthesis of $\mathrm{Ag}_{2.0} \mathrm{Cu}_{2.0} \mathrm{HAlBeta}$ and $\mathrm{Ag}_{2.0} \mathrm{Cu}_{2.0} \mathrm{SiBeta}$ zeolites by conventional wet impregnation and twostep postsynthesis methods, respectively. The calcination of $\mathrm{Ag}_{2.0} \mathrm{Cu}_{2.0} \mathrm{HAlBeta}$ and $\mathrm{Ag}_{2.0} \mathrm{Cu}_{2.0} \mathrm{SiBeta}$ at $773 \mathrm{~K}$ for $3 \mathrm{~h}$ in air led to formation of $\mathrm{C}-\mathrm{Ag}_{2.0} \mathrm{Cu}_{2.0} \mathrm{HAlBeta}$ and $\mathrm{C}$ $\mathrm{Ag}_{2.0} \mathrm{Cu}_{2.0}$ SiBeta. After reduction at $873 \mathrm{~K}$ for $3 \mathrm{~h}$ in flowing $10 \% \mathrm{H}_{2} / \mathrm{Ar}$, red-C$\mathrm{Ag}_{2.0} \mathrm{Cu}_{2.0} \mathrm{HAlBeta}$ and red-C- $\mathrm{Ag}_{2.0} \mathrm{Cu}_{2.0} \mathrm{SiBeta}$ were obtained and investigated as the catalysts in gas phase hydrodechlorination of 1,2-dichloroethane at atmospheric pressure, at relatively low reaction temperature $(523 \mathrm{~K})$. The state of silver and copper in catalysts at different stages of their biography was characterized by low-temperature $\mathrm{N}_{2}$ sorption, temperature programmed reduction (TPR), transmission electron microscopy (TEM), X-ray diffraction (XRD), X-ray photoelectron spectroscopy (XPS), and temperature- programmed hydrogenation (TPH). We have shown that the state of silver and copper species change under HDC conditions. After catalytic run both agglomeration of metal particles and their redispersion took place. According to TPH, XRD and XPS measurements we postulate that the cause of this phenomenon is the formation of chlorine containing species in spent zeolite catalysts.

Keywords: Ag, Cu, Beta, hydrodechlorination, 1,2-dichloroethane, physicochemical characterization 


\section{Introduction}

Hydrodechlorination is known as structural sensitive reaction, but among the researchers opinions are divided on the effect of metal(s) dispersion and metal particle size on this process $[1,2]$. Some of the literature data clearly show the beneficial role of excellent dispersed very small metal particles in the gas - phase hydrodechlorination [2-4]. Our recent studies on nickel containing beta zeolite in conversion of 1,2-dichloroethane brightly demonstrated the high stability, and high selectivity of very small $(\sim 1.5 \mathrm{~nm})$ nickel particles [5]. In spite of earlier reports the small metal particles did not deactivate during reaction and they are resistant to sintering $[5,6]$. As we have earlier shown, the application of dealuminated SiBeta zeolite with vacant T-atom sites played an important role on the formation stable, active and selective catalysts $[5,6]$.

Very interesting results were obtained also for bimetallic $\mathrm{Cu}-\mathrm{Ni}$ systems prepared by twostep postsynthesis method [7]. Careful investigations have shown very good activity of bimetallic $\mathrm{Cu}-\mathrm{Ni}$ zeolite catalysts containing small and well dispersed $\mathrm{Ni}(0)$ and $\mathrm{Cu}(0)$ nanoparticles in hydrodechlorination of 1,2-dichloroethane and high selectivity to ethylene.

Our earlier works [5-8] clearly show that depending on the kind of synthesis method, zeolite catalysts more or less change upon hydrodechlorination conditions. Prepared by twostep postsynthesis method nickel, silver, nickel - silver and nickel - copper containing SiBeta catalysts have shown resistance for changes in aggressive reaction conditions. On the other hand $\mathrm{Ni}, \mathrm{Ni}-\mathrm{Cu}, \mathrm{Ag}, \mathrm{Ni}-\mathrm{Ag}$ containing HAlBeta catalysts synthesized by conventional wet impregnation were more sensitive for sintering and poisoning by carbon and chlorine containing deposits during HDC process [5-8].

Inspired by our earlier works we would like to investigate the effect of two-step postsynthesis method of preparation on catalytic properties of silver and copper loaded bimetallic Beta zeolite catalysts in the hydrodechlorination of 1,2-dichloroethane and 
especially on physicochemical properties of zeolite catalysts containing $\mathrm{Ag}-\mathrm{Cu}$ at various stages of their biographies.

\section{Experimental}

\subsection{Catalysts preparation}

A tetraethylammonium Beta $($ TEABeta) $(\mathrm{Si} / \mathrm{Al}=17)$ zeolite provided by RIPP (China) was calcined at $823 \mathrm{~K}$ for $15 \mathrm{~h}$ in air to remove template. Organic-free HAlBeta zeolite was treated with $13 \mathrm{~mol} \cdot \mathrm{L}^{-1}$ nitric acid $(353 \mathrm{~K}, 4 \mathrm{~h})$ to obtain dealuminated SiBeta zeolite, with $\mathrm{Si} / \mathrm{Al}$ ratio higher than 1300 , and then washed several times with distilled water and dried at $363 \mathrm{~K}$ overnight.

$\mathrm{Ag}_{2.0} \mathrm{Cu}_{2.0} \mathrm{HAlBeta}$ and $\mathrm{Ag}_{2.0} \mathrm{Cu}_{2.0}$ SiBeta were prepared by co-impregnation of $2 \mathrm{~g}$ of HAlBeta and SiBEA, respectively, with appropriate concentration of aqueous solutions of $\mathrm{AgNO}_{3}\left(\mathrm{c}=3.6^{\cdot} 10^{-3} \mathrm{~mol} \mathrm{~L}^{-1}\right)$ and $\mathrm{Cu}\left(\mathrm{NO}_{3}\right)_{2}\left(\mathrm{c}=2.2 \cdot 10^{-3} \mathrm{~mol} \mathrm{~L}{ }^{-1}\right)$. Firstly, both suspensions were stirred for $24 \mathrm{~h}$ at $298 \mathrm{~K}$ in excess solvent using $200 \mathrm{~mL}$ of the precursor solutions. Then, the suspensions were stirred in evaporator under vacuum of a water pump for $2 \mathrm{~h}$ in air at $333 \mathrm{~K}$ until the water was evaporated. As prepared $\mathrm{Ag}_{2.0} \mathrm{Cu}_{2.0} \mathrm{HAlBeta}$ and $\mathrm{Ag}_{2.0} \mathrm{Cu}_{2.0}$ SiBeta were further calcined at $773 \mathrm{~K}$ for $3 \mathrm{~h}$ in static air and labeled $\mathrm{C}-\mathrm{Ag}_{2.0} \mathrm{Cu}_{2.0} \mathrm{HAlBeta}$ and $\mathrm{C}$ $\mathrm{Ag}_{2.0} \mathrm{Cu}_{2.0} \mathrm{SiBeta}$, respectively. Then, C- $\mathrm{Ag}_{2.0} \mathrm{Cu}_{2.0} \mathrm{HAlBeta}$ and $\mathrm{C}-\mathrm{Ag}_{2.0} \mathrm{Cu}_{2.0} \mathrm{SiBeta}$ were reduced at $873 \mathrm{~K}$, for $3 \mathrm{~h}$ in flowing $10 \% \mathrm{H}_{2} / \mathrm{Ar}$ to obtain red-C- $\mathrm{Ag}_{2.0} \mathrm{Cu}_{2.0} \mathrm{HAlB}$ ta and redC- $\mathrm{Ag}_{2.0} \mathrm{Cu}_{2.0} \mathrm{SiBeta}$, respectively, where $\mathrm{C}$ - stands for calcined and red- for reduced. The catalysts after kinetic run were labeled as spent-red-C- $\mathrm{Ag}_{2.0} \mathrm{Cu}_{2.0} \mathrm{HAlBeta}$ and spent-red-C$\mathrm{Ag}_{2.0} \mathrm{Cu}_{2.0} \mathrm{SiBeta}$, respectively.

\subsection{Catalyst characterization}

Specific surface area and adsorption isotherms of nitrogen at $77 \mathrm{~K}$ were measured on a Micromeretics ASAP 2020 apparatus, employing the BET (Brunauer-Emmett-Teller) and HK 
(Horwath-Kawazoe) methods using nitrogen as adsorbate. Before measuring the adsorption isotherm at $77 \mathrm{~K}$, the samples were kept at $473 \mathrm{~K}$ for $4 \mathrm{~h}$ in vacuum to remove adsorbed water and gases. The specific surface areas were determined from nitrogen adsorption values from $\mathrm{p} / \mathrm{p}_{0}=0.05$ to $0.30 \mathrm{using} \mathrm{BET}$ method. The maximum pore volume at $\mathrm{p} / \mathrm{p}_{0}=0.2$ was determined using HK method.

Temperature-programmed reduction for all of the catalysts, after calcination step, was carried out using the glass-flow system. TPR runs were performed in flowing $10 \% \mathrm{H}_{2} / \mathrm{Ar}(25$ $\mathrm{cm}^{3} \min ^{-1}$ ), ramping the temperature at $10 \mathrm{~K} \mathrm{~min}^{-1}$ and using a Gow-Mac thermal conductivity detector (TCD). Injections of known amounts of hydrogen into the hydrogenargon flow were provided for calibration (before and after each TPR run).

Catalytic hydrodechlorination of 1,2-dichloroethane (1,2-DCE, HPLC grade, 99.8\% pure from Sigma-Aldrich, Germany) was performed at glass flow system at atmospheric pressure, at the temperature of $523 \mathrm{~K}$. The reaction was followed by gas chromatography, using a HP5890 series II gas chromatograph with Flame Ionization Detector (FID), a 5\% Fluorcol/Carbopack B column (10 ft) from Supelco. The results of GC analysis were elaborated using HP Chemstation. The total FID signal from the first two analyses was similar to that observed in subsequent GC analyses.

Transmission Electron Microscopy was performed on a JEOL JEM 2100 FEG microscope of the Institut de Mineralogie et de Physique des Milieux Condenses (Université Pierre et Marie Curie) operating at $200 \mathrm{kV}$, equipped with X-ray energy dispersive spectroscopy for chemical analysis, with $1 \mathrm{~nm}$ beam size. Samples were prepared for TEM observations by dispersing the powder ultrasonically in ethanol and depositing a drop on the carbon film. TEM observations were carried out using a Beryllium TEM holder enabling chemical analysis of copper. 
X-ray diffractograms for the samples at various stages of their biographies were recorded at room temperature on a PANalytical Empyrean diffractometer using the $\mathrm{CuK} \alpha$ radiation $(\lambda=154.05 \mathrm{pm})$.

The X-ray photoelectron spectroscopy measurements were done using an Omicron (ESCA+) X-ray photoelectron spectrometer. The base pressure in the experimental chamber was in the low $10^{-9}$ mbar range. The spectra were collected using a monochromatic $\mathrm{Al} \mathrm{K \alpha}$ $(h v=1486.6 \mathrm{eV}) \mathrm{X}$-ray source with an accelerating voltage of $14 \mathrm{kV}$ and a current intensity of $20 \mathrm{~mA}$. The pass energy was $20 \mathrm{eV}$ for the high resolution spectra and $100 \mathrm{eV}$ for the surveys. Surface charging effects were compensated by referencing the BE (binding energy) to the $\mathrm{C} 1 \mathrm{~s}$ line of residual carbon set at $284.7 \mathrm{eV} \mathrm{BE}$.

Temperature-programmed hydrogenation was carried out by mass spectrometry (MA200, Dycor-Ametek, Pittsburgh) to detect a compound that can be removed by hydrogen from spent catalysts. During the experiments, the samples after conversion of 1,2dichloroethane were heated from $\sim 298 \mathrm{~K}$ to $1073 \mathrm{~K}$ in the flow of $20 \% \mathrm{H}_{2} / \mathrm{He}$ with ramp rate $10 \mathrm{~K} \mathrm{~min}^{-1}$ and with monitoring of twelve masses $(\mathrm{m} / \mathrm{z})$.

\section{Results and Discussion}

Nitrogen adsorption-desorption isotherms are shown in Fig. 1. The open symbols represent adsorption, while the filled ones represent desorption data for the C$\mathrm{Ag}_{2.0} \mathrm{Cu}_{2.0} \mathrm{SiBeta}$ and $\mathrm{C}-\mathrm{Ag}_{2.0} \mathrm{Cu}_{2.0} \mathrm{HAlBeta}$ samples. They exhibit the type $\mathrm{I}$ isotherm according to IUPAC $[9,10]$, indicating that they have a microporous structure. All zeolite materials have similar BET surface area and micropore volume (Table 1). It is indicating that textural properties of Beta zeolite are preserved upon both methods of their preparation. However,C- $\mathrm{Ag}_{2.0} \mathrm{Cu}_{2.0} \mathrm{HAlBeta}$ zeolite has a little lower specific surface area, probably due to the formation of silver and/or copper oxide that may block access to some pores. Pore size 
distribution of $\mathrm{C}-\mathrm{Ag}_{2.0} \mathrm{Cu}_{2.0} \mathrm{SiBeta}$ and $\mathrm{C}-\mathrm{Ag}_{2.0} \mathrm{Cu}_{2.0} \mathrm{HAlBeta}$ calculated from HorvathKawazoe function were shown in Figure S1 (Supplementary data). The pore volume dependence $\left(\mathrm{cm}^{3} \mathrm{~g}^{-1}\right)$ on the weighted average pore size $(\mathrm{nm})$ is similar in both cases. However, some differences have been observed especially in the case of the smaller pore size.

Temperature-programmed reduction experiments were carried out to determine the reducibility of silver and copper in $\mathrm{C}-\mathrm{Ag}_{2.0} \mathrm{Cu}_{2.0} \mathrm{SiBeta}$ and $\mathrm{C}-\mathrm{Ag}_{2.0} \mathrm{Cu}_{2.0} \mathrm{HAlBeta}$ zeolites, respectively. As shown in Fig. 2, TPR profile for $\mathrm{C}-\mathrm{Ag}_{2.0} \mathrm{Cu}_{2.0} \mathrm{SiBeta}$ contains six reduction peaks and the TPR profile for $\mathrm{C}-\mathrm{Ag}_{2.0} \mathrm{Cu}_{2.0} \mathrm{HAlBeta}$ contains seven peaks. Comparative study between TPR profiles forC- $\mathrm{Ag}_{2.0} \mathrm{Cu}_{2.0} \mathrm{SiBeta}$ and $\mathrm{C}-\mathrm{Ag}_{2.0} \mathrm{Cu}_{2.0} \mathrm{HAlBeta}$ zeolites and TPR profiles for monometallic copper [7] and monometallic silver [11] based on the same zeolite materials (HAlBeta and SiBeta) clearly show an interaction between $\mathrm{Ag}$ and $\mathrm{Cu}$. Coexistence of $\mathrm{Ag}$ and $\mathrm{Cu}$ species leads to the shift of the reduction peaks of silver species toward higher temperatures and copper species toward lower temperatures. Our results are in agreement with earlier studies on bimetallic Ag-Cu species [12]. This effect is clearly seen especially in the case of $\mathrm{C}-\mathrm{Ag}_{2.0} \mathrm{Cu}_{2.0} \mathrm{HAlBeta}$, where two main reduction peaks are observed. One of them, at $468 \mathrm{~K}$, could be assigned to the reduction of Ag species. This maximum is shifted to higher temperature in comparison with the maximum at $466 \mathrm{~K}$ for $\mathrm{C}-\mathrm{Ag}_{2.0} \mathrm{HAlBeta}$ [11]. On the other hand, the maximum of the peak at $512 \mathrm{~K}$ in case of $\mathrm{C}-\mathrm{Ag}_{2.0} \mathrm{Cu}_{2.0} \mathrm{HAlBeta}$ might be attributed to the reduction of copper species. This maximum is significantly shifted to lower temperature, in comparison with the TPR profile for $\mathrm{C}-\mathrm{Cu}_{2.0} \mathrm{HAlBeta}$ [7]. Similarly, the shift of the maximum of the reduction peak toward higher temperatures for silver species and to lower temperatures for copper species is observed in the case of TPR profile for C$\mathrm{Ag}_{2.0} \mathrm{Cu}_{2.0} \mathrm{SiBeta}$. This phenomenon confirms the interaction between $\mathrm{Cu}$ and $\mathrm{Ag}$, as it was reported earlier [13]. 
Additional signals in the range of $322-380 \mathrm{~K}$ for both zeolite samples could be assigned to the reduction of, existing separately, an excellent dispersed mononuclear $\operatorname{Ag}(\mathrm{I})$ and/or silver oxides to metallic $\mathrm{Ag}^{0}$ form, in agreement with earlier works on silver based catalysts $[14,15]$. On the other hand, presence of high temperature peaks, at $711 \mathrm{~K}$ in the case of $\mathrm{C}-\mathrm{Ag}_{2.0} \mathrm{Cu}_{2.0} \mathrm{HAlBeta}$ and at $692 \mathrm{~K}$ in the case of $\mathrm{C}-\mathrm{Ag}_{2.0} \mathrm{Cu}_{2.0} \mathrm{SiBeta}$ could be related to the reduction of mononuclear isolated $\mathrm{Ag}$ and $\mathrm{Cu}$ species. Therefore, we could postulate that independently of the synthesis method, conventional wet impregnation or two-step postsynhesis method, the reduced form of zeolite catalysts contain both monometallic silver and copper nanoparticles and bimetallic Ag-Cu alloys.

As shown in Fig. 3, red-C- $\mathrm{Ag}_{2.0} \mathrm{Cu}_{2.0}$ SiBeta displays very low activity during $>1000$ minutes of 1,2-dichloroethane hydrodechlorination with conversion less than $1 \%$. The conversion at the level of $\sim 2 \%$ is observed only during the first 3 minutes of the reaction. The catalytic behaviour of red-C- $\mathrm{Ag}_{2.0} \mathrm{Cu}_{2.0} \mathrm{SiBeta}$ is very similar to that observed for pure red-CSiBeta and red-C-Cu $\mathrm{Cu}_{2.0} \mathrm{SiBeta}$ catalysts [7] and it is in contrast with the results obtained for monometallic red-C-Ag ${ }_{2.0} \mathrm{SiBeta}$ catalyst [11]. It means that the coexistence of $\mathrm{Cu}$ and $\mathrm{Ag}$ does not influent on the increasing of the activity of zeolite materials. However, higher conversion observed after 3 minutes of the reaction could suggest rapid deactivation of red-C$\mathrm{Ag}_{2.0} \mathrm{Cu}_{2.0} \mathrm{SiBeta}$ under reaction conditions or the catalyst undergoes some equilibration in the initial phase of hydrodechlorination of 1,2-dichloroethane.

In contrast, red-C- $\mathrm{Ag}_{2.0} \mathrm{Cu}_{2.0} \mathrm{HAlBeta}$ exhibits higher than $6 \%$ of 1,2-DCE conversion after $16 \mathrm{~h}$ of reaction. For this zeolite catalyst the activation taken place during the first 100 min. of 1,2-DCE hydrodechlorination and afterwards slow deactivation is observed (Fig. 3). The similar results obtained for red-C- $\mathrm{Ag}_{2.0} \mathrm{Cu}_{2.0} \mathrm{HAlBeta}$ and pure red-C-HAlBeta [7] display lower activity and higher stability of bimetallic $\mathrm{Ag}-\mathrm{Cu}$ catalyst. It could indicate that the state of bimetallic $\mathrm{Ag}-\mathrm{Cu}$ species have changed under reaction conditions. 
The application of both red-C- $\mathrm{Ag}_{2.0} \mathrm{Cu}_{2.0} \mathrm{SiBeta}$ and red-C- $\mathrm{Ag}_{2.0} \mathrm{Cu}_{2.0} \mathrm{HAlBeta}$ in HDC reaction leads to formation of desired product of 1,2-dichloroethane hydrodechlorination such as ethylene and vinyl chloride (Figs 4 and 5). Although the coexistence of $\mathrm{Ag}$ and $\mathrm{Cu}$ in red$\mathrm{C}-\mathrm{Ag}_{2.0} \mathrm{Cu}_{2.0} \mathrm{SiBeta}$ does not affect the activity of catalyst, it is visible in the product distribution. During the first minutes of the reaction $\sim 50 \%$ of $\mathrm{C}_{2} \mathrm{H}_{4}$ and $\sim 50 \%$ of $\mathrm{C}_{2} \mathrm{H}_{3} \mathrm{Cl}$ were formed in the case of red-C- $\mathrm{Ag}_{2.0} \mathrm{Cu}_{2.0} \mathrm{SiBeta}$, while $100 \%$ of vinyl chloride is observed for red-C-SiBeta [7]. Additionally, the selectivity toward ethylene increased during the time at the expense of the selectivity to vinyl chloride. After 1000 minutes of the reaction the selectivity to ethylene was $74 \%$ and to vinyl chloride $26 \%$ (Figs. 4 and 5). This phenomenon confirms our suppositions that the catalyst surface is modified under HDC 1,2-dichloroethane conditions. However, in the case of red-C- $\mathrm{Ag}_{2.0} \mathrm{Cu}_{2.0} \mathrm{HAlBeta}$ the presence of $\mathrm{Ag}$ and $\mathrm{Cu}$ does not affect the selectivity toward products of 1,2-dichloroethane hydrodechlorination. Red-C$\mathrm{Ag}_{2.0} \mathrm{Cu}_{2.0} \mathrm{HAlBeta}$ alike of red-C-HAlBeta shows $\sim 100 \%$ selectivity toward vinyl chloride [7]. It could suggest that the presence of both Brønsted and Lewis acidic sites plays an important role in catalytic behaviour of red-C- $\mathrm{Ag}_{2.0} \mathrm{Cu}_{2.0} \mathrm{HAlBeta}$ catalyst.

TEM measurements were carried out for red-C- $\mathrm{Ag}_{2.0} \mathrm{Cu}_{2.0} \mathrm{SiBeta}$, red-C$\mathrm{Ag}_{2.0} \mathrm{Cu}_{2.0} \mathrm{HAlBeta}$, spent-red-C- $\mathrm{Ag}_{2.0} \mathrm{Cu}_{2.0} \mathrm{SiBeta}$ and spent-red-C- $\mathrm{Ag}_{2.0} \mathrm{Cu}_{2.0} \mathrm{HAlBeta}$. The correlation of the samples composition and nanoparticles sizes leads to classify particles in two categories (Figs 6-9):

i) small bimetallic nanoparticles slightly monodisperse in size $(5 \mathrm{~nm}$ for red-C$\mathrm{Ag}_{2.0} \mathrm{Cu}_{2.0} \mathrm{HAlBeta}$ and $3 \mathrm{~nm}$ for red-C- $\left.\mathrm{Ag}_{2.0} \mathrm{Cu}_{2.0} \mathrm{SiBeta}\right)$ but with heterogeneous composition (from $20 \%$ to $95 \%$ of $\mathrm{Ag}$ ).

ii) larger nanoparticles, heterogeneous in size (from 10 to $50 \mathrm{~nm}$ ) in the case of red$\mathrm{C}-\mathrm{Ag}_{2.0} \mathrm{Cu}_{2.0} \mathrm{HAlBeta}$ and red-C- $\left.\mathrm{Ag}_{2.0} \mathrm{Cu}_{2.0} \mathrm{SiBeta}\right)$ but with homogenous composition (95\% Ag). 
The presence of large monometallic silver nanoparticles are in agreement with XRD results too.

In the case of spent-red-C- $\mathrm{Ag}_{2.0} \mathrm{Cu}_{2.0} \mathrm{HAlBeta}$, additional third category of nanoparticles was observed. Monometallic copper small nanoparticles with an average particles diameter from 2 to $5 \mathrm{~nm}$ were found. It seems that small copper nanoparticles were formed by aggregation of very small copper clusters that could not be observed for red-C$\mathrm{Ag}_{2.0} \mathrm{Cu}_{2.0} \mathrm{HAlBeta}$ due to resolution limits of the microscope.

On the other hand, in the case of red-C- $\mathrm{Ag}_{2.0} \mathrm{Cu}_{2.0} \mathrm{HAlBeta}$ we could observe only one category of slightly monometallic (95\% Ag) nanoparticles with diameters from $3 \mathrm{~nm}$ to 50 $\mathrm{nm}$. It seems that bimetallic nanoparticles lost $\mathrm{Cu}$ and became $\mathrm{Ag}$ nanoparticles. We can think also that very small $\mathrm{Cu}$ nanoparticles (diameter $<2 \mathrm{~nm}$ ) were formed but could not be observed due to instrumental resolution limitation.

The effect of re-dispersion of active phase under HDC conditions is indicated especially for noble metals such as Pt and Pd [16,17]. This phenomenon is usually explained by the formation, volatilisation and re-deposition of unstable metallic chlorides resulting from the reaction between metallic particle and $\mathrm{HCl}$ [16-18]. In agreement with earlier study of Fung and Sinfelt [19], concerning the hydrogenolysis of methyl chloride $\mathrm{CH}_{3} \mathrm{Cl}$ on metals from group IB, they are able to form a metal-chlorine bond, as demonstrated by the existence of stable chlorides.

Consequently, the formation of smaller metal particles could lead to a stronger reactant-surface interaction, and therefore to an increase in the selectivity for more dechlorinated molecule. Therefore, during 1,2-dichloroethane hydrodechlorination on red-C$\mathrm{Ag}_{2.0} \mathrm{Cu}_{2.0} \mathrm{SiBeta}$ gradual increasing of the selectivity to ethylene was observed (Fig. 4), at the expense of decreasing selectivity toward vinyl chloride (Fig. 5). In this way, hydrodechlorination is considered as structure-sensitive reaction $[6,16,17]$. 
On the other hand, the formation of volatile metallic chlorides, such as $\mathrm{Cu}_{\mathrm{x}} \mathrm{Cl}_{\mathrm{y}}$ could lead to their migration and re-dispersion of active phase $[19,20]$. The reduction of chlorides by the hydrogen introduced as reactant could lead to formation of much smaller metal particles [20]. These phenomena could be the reason of disappearance of $\mathrm{Cu}$ in TEM images for spent zeolite catalysts.

Figs. 10 and 11 show the XRD results for both zeolite HAlBeta and SiBeta supports and for Ag-Cu containing HAlBeta and SiBeta catalysts on different stages of their biography (for as prepared, reduced and spent samples). They are characterized by high crystallinity and correspond to Beta-type zeolite structure. It indicates that calcination (at $823 \mathrm{~K}$ during $15 \mathrm{~h}$ ), dealumination with nitric acid, reduction at $873 \mathrm{~K}$ during $3 \mathrm{~h}$ and hydrodechlorination processes did not affect crystallinity of the zeolite catalysts.

Moreover, as prepared $\mathrm{Ag}$ and $\mathrm{Cu}$ loaded zeolite samples do not show any evidence of extra-framework compound or amorphization of the zeolite, indicating good dispersion of nickel and copper in zeolite structure. A change of the position of the narrow main diffraction peak around $2 \theta$ of $22.60^{\circ}$, generally taken as evidence of framework contraction/expansion of BEA structure, from $22.54^{\circ}$ for HAlBeta to $22.46^{\circ}$ for $\mathrm{Ag}_{2.0} \mathrm{Cu}_{2.0} \mathrm{HAlBeta}$ and from $22.86^{\circ}$ for SiBeta to $22.59^{\circ}$ for $\mathrm{Ag}_{2.0} \mathrm{Cu}_{2.0} \mathrm{SiBeta}$ indicates matrix expansion and incorporation of metals ions into the framework of Beta zeolite (Figs. 10 and 11). For red-C- $\mathrm{Ag}_{2.0} \mathrm{Cu}_{2.0} \mathrm{HAlBeta}$ (Fig. 10) and red-C- $\mathrm{Ag}_{2.0} \mathrm{Cu}_{2.0}$ SiBeta (Fig. 11) additional phase of $\mathrm{Ag}$ is observed suggesting sintering and formation of big monometallic silver crystallites after reduction step. These XRD results are in agreement with the data obtained for TEM measurements.

Catalytic conversion of 1,2-dichloroethane involves additional changes in the structure of the zeolite catalysts. They contain additionally reflexes related to $\mathrm{AgCl}$ and $\mathrm{CuCl}_{2}$ salts (Figs 10 and 11) which is a signature of the formation and agglomeration of silver and copper chlorine in both catalysts. This could be the reason of rapid deactivation of these catalysts 
during hydrodechlorination of 1,2-dichloroethane, as it was reported earlier for silver and copper containing catalysts in HDC process [7,11].

In the $\mathrm{C} 1 \mathrm{~s}$ XP spectra of red-C- $\mathrm{Ag}_{2.0} \mathrm{Cu}_{2.0} \mathrm{HAlBeta}$, spent-red-C- $\mathrm{Ag}_{2.0} \mathrm{Cu}_{2.0} \mathrm{HAlBeta}$, red-C- $\mathrm{Ag}_{2.0} \mathrm{Cu}_{2.0} \mathrm{SiBeta}$ and spent-red-C- $\mathrm{Ag}_{2.0} \mathrm{Cu}_{2.0} \mathrm{SiBeta}$ there are three main contributions at 284.7, 285.8 - 286.0 and 287.0 - $287.5 \mathrm{eV}$, corresponding respectively to i) $\mathrm{C}-\mathrm{C}$ and $\mathrm{C}-\mathrm{H}$, ii) $\mathrm{C}-\mathrm{O}$ and $\mathrm{C}-\mathrm{N}$ and iii) $\mathrm{C}=\mathrm{O}$ bindings (results not shown). In the $\mathrm{O} 1 \mathrm{~s}$ spectra of these samples, one peak is observed at c.a. $532.7-533.7 \mathrm{eV}$ (result not shown) that is attributed to Si-O-Si bond [21]. The Si $2 \mathrm{p}$ spectra for all tested samples exhibit a peak at c.a. $103.5-104.5 \mathrm{eV}$ (results not shown) related to energy binding of Si $2 p$ present in the structure of zeolite [22].

XPS was used to determine the valence state of the silver and copper species in red-C$\mathrm{Ag}_{2.0} \mathrm{Cu}_{2.0} \mathrm{HAlBeta}$, spent-red-C- $\mathrm{Ag}_{2.0} \mathrm{Cu}_{2.0} \mathrm{HAlBeta}$, red-C- $\mathrm{Ag}_{2.0} \mathrm{Cu}_{2.0}$ SiBeta and spent-red-C$\mathrm{Ag}_{2.0} \mathrm{Cu}_{2.0} \mathrm{SiBeta}$. Figure $\mathbf{S} 2$ shows the $\mathrm{Ag} 3 \mathrm{~d}_{3 / 2}$ and $3 \mathrm{~d}_{5 / 2}$ bands of red-C- $\mathrm{Ag}_{2.0} \mathrm{Cu}_{2.0} \mathrm{HAlBeta}$ and spent-red-C- $\mathrm{Ag}_{2.0} \mathrm{Cu}_{2.0} \mathrm{HAlBeta}$. Binding energies (BE) of $\mathrm{Ag} 3 \mathrm{~d}_{5 / 2}(369 \mathrm{eV})$ and $\mathrm{Ag} 3 \mathrm{~d}_{3 / 2}$ (375 eV) for spent-red-C- $\mathrm{Ag}_{2.0} \mathrm{Cu}_{2.0} \mathrm{HAlBEA}$ differ slightly $(0.5 \mathrm{eV}$ ) from the $\mathrm{BE}$ observed for red-C- $\mathrm{Ag}_{2.0} \mathrm{Cu}_{2.0} \mathrm{HAlBeta}(368.5$ and $374.5 \mathrm{eV}$ ). The increase of the binding energy of $\mathrm{Ag}$ $3 \mathrm{~d}$ bands after hydrodechlorination of 1,2-dichloroethane on red-C- $\mathrm{Ag}_{2.0} \mathrm{Cu}_{2.0} \mathrm{HAlBeta}$ could indicate oxidation of silver upon this reaction.

The $\mathrm{Cu} 2 \mathrm{p}$ XPS spectrum of red-C- $\mathrm{Ag}_{2.0} \mathrm{Cu}_{2.0} \mathrm{HAlBeta}$ and spent-red-C$\mathrm{Ag}_{2.0} \mathrm{Cu}_{2.0} \mathrm{HAlBeta}$ is deconvoluted into two doublets (Fig. S3). In the $2 \mathrm{p}_{3 / 2}$ range the most intensive peak appears at $933.7-933.5 \mathrm{eV}$ and the second peak at $936.5-935.8 \mathrm{eV}$. Both peaks are characteristic of $\mathrm{Cu}(\mathrm{II})$, first one probably of well dispersed pseudo-tetrahedral $\mathrm{Cu}(\mathrm{II})$ and the second one of octahedrally coordinated $\mathrm{Cu}(\mathrm{II})$, in line with earlier reports [23, 24]. In the $2 p_{1 / 2}$ range the most intensive peak appears at $953.6-953.3 \mathrm{eV}$ and the second one at 956.5 - $956 \mathrm{eV}$ (Fig. S3). Absence of satellite peaks which could be identified to $\mathrm{Cu}(\mathrm{II})$ is 
probably due to very high dispersion and strong interaction of $\mathrm{Cu}$ (II) ions with zeolite matrix, in line with earlier reports $[23,24]$.

In the case of red-C- $\mathrm{Ag}_{2.0} \mathrm{Cu}_{2.0}$ SiBeta and spent-red-C- $\mathrm{Ag}_{2.0} \mathrm{Cu}_{2.0}$ SiBeta BE of $\mathrm{Ag} 3 \mathrm{~d}_{5 / 2}$ and $\mathrm{Ag} 3 \mathrm{~d}_{3 / 2}$ are very close and equal 369.1 - 369.0 and 375.1 - $375.0 \mathrm{eV}$, respectively (Fig. S4). XPS results show that $\mathrm{BE}$ of $\mathrm{Ag} 3 \mathrm{~d}_{5 / 2}$ and $\mathrm{Ag} 3 \mathrm{~d}_{3 / 2}$ do not change during hydrodechlorination of 1,2-dichloroethane on red-C- $\mathrm{Ag}_{2.0} \mathrm{Cu}_{2.0} \mathrm{SiBeta}$.

In the case of red-C- $\mathrm{Ag}_{2.0} \mathrm{Cu}_{2.0} \mathrm{SiBeta}$ and spent-red-C- $\mathrm{Ag}_{2.0} \mathrm{Cu}_{2,0} \mathrm{SiBeta} \mathrm{BE}$ of $\mathrm{Cu} 2 \mathrm{p}$ peaks appears as two doublets in the $2 \mathrm{p}_{1 / 2}$ and $2 \mathrm{p}_{3 / 2}$ ranges (Fig. S5). In the $2 \mathrm{p}_{3 / 2}$ range the most intensive peak appears at $934.9-933.6 \mathrm{eV}$ and the second peak at $937.1-935.9 \mathrm{eV}$. Both peaks are characteristic of $\mathrm{Cu}$ (II), first one probably of well dispersed pseudo-tetrahedral $\mathrm{Cu}$ (II) and the second one of octahedrally coordinated $\mathrm{Cu}$ (II), in line with earlier reports $[23,24]$. In the $2 p_{1 / 2}$ range the most intensive peak appears at $954.8-954.0 \mathrm{eV}$ and the second one at 957.1 - $956.4 \mathrm{eV}$ (Fig. S5). Moreover, according to Yea et al. [25], the presence of $\mathrm{Cu}$ (II) species can be confirmed by appearance of shake-up satellite peaks at $942.2-945.0$ and $962.3-964.3 \mathrm{eV}$, characteristic of $\mathrm{Cu}(\mathrm{II})$ species and they evidence of an open $3 \mathrm{~d}^{9}$ shell $[26,27]$.

Very interesting information follows from the TPH (temperature - programmed hydrogenation) of deposit retained by the spent-red-C- $\mathrm{Ag}_{2.0} \mathrm{Cu}_{2.0} \mathrm{SiBeta}$ and spent-red-C$\mathrm{Ag}_{2.0} \mathrm{Cu}_{2.0} \mathrm{HAlBeta}$. During hydrodechlorination of 1,2-dichloroethane on $\mathrm{Ag}-\mathrm{Cu}$ catalysts both carbon and chlorine species were formed. Significant differences observed for spent-red$\mathrm{C}-\mathrm{Ag}_{2.0} \mathrm{Cu}_{2.0} \mathrm{HAlBeta}$ and spent-red-C- $\mathrm{Ag}_{2.0} \mathrm{Cu}_{2.0} \mathrm{SiBeta}$ were shown by the representative data obtained for the $m / z 15\left(\mathrm{CH}_{4}\right), \mathrm{m} / z 28\left(\mathrm{C}_{2} \mathrm{H}_{\mathrm{x}}\right)$ and $\mathrm{m} / \mathrm{z} 62\left(\mathrm{C}_{2} \mathrm{H}_{\mathrm{x}} \mathrm{Cl}\right)$ and $\mathrm{m} / \mathrm{z} 36(\mathrm{HCl})$ respectively (Figs 12 and 13). Comparison study between both spent Ag-Cu catalysts suggests negligible amounts of carbonaceous species on spent-red-C- $\mathrm{Ag}_{2.0} \mathrm{Cu}_{2.0} \mathrm{SiBeta}$ and significant amounts of carbonaceous species on spent-red-C- $\mathrm{Ag}_{2.0} \mathrm{Cu}_{2.0} \mathrm{HAlBeta}$. Additionally, very high 
temperature (> $800 \mathrm{~K}$ ) needs for the removal of these deposits from catalyst surface, suggests a very strong interaction between deposits and the spent-red-C- $\mathrm{Ag}_{2.0} \mathrm{Cu}_{2.0} \mathrm{HAlBeta}$ surface. This phenomenon could suggest the carburization of the Brønsted and Lewis acidic sites under reaction conditions.

$\mathrm{HCl}\left(\mathrm{m} / \mathrm{z}\right.$ 36) (Figs 12 and 13) liberation for spent-red-C- $\mathrm{Ag}_{2.0} \mathrm{Cu}_{2.0} \mathrm{SiBeta}$ and spentred-C- $\mathrm{Ag}_{2.0} \mathrm{Cu}_{2.0} \mathrm{HAlBeta}$ means that the accumulation of chlorine species on both these catalysts during HDC process is strongly related to the presence of $\mathrm{Ag}$ and $\mathrm{Cu}$ metals. Evolution of $\mathrm{m} / \mathrm{z} 62$ for both catalysts confirms the formation of deposits containing both carbon and chlorine.

$\mathrm{TPH}$ results obtained for spent-red-C- $\mathrm{Ag}_{2.0} \mathrm{Cu}_{2.0} \mathrm{HAlBeta}$ and spent-red-C$\mathrm{Ag}_{2.0} \mathrm{Cu}_{2.0} \mathrm{SiBeta}$ are in agreement with our earlier studies for nickel containing Beta zeolite $[6]$.

\section{Conclusions}

The investigation realized in this work clearly shows that the two-step postsynthesis method leads to the formation mainly very small, $\mathrm{Ag}$ and $\mathrm{Cu}$ nanoparticles in reduced form of the catalyst.

Application of red-C- $\mathrm{Ag}_{2.0} \mathrm{Cu}_{2.0} \mathrm{HAlBeta}$ catalyst in 1,2-dichloroethane hydrodechlorination gives almost $100 \%$ selectivity into vinyl chloride, desired product of this reaction, in contrast, application of red-C- $\mathrm{Ag}_{2.0} \mathrm{Cu}_{2.0}$ SiBeta gives ethylene as a main product which is second desired products of this reaction.

Under HDC process on the both catalysts carbon and chlorine species are deposited. We have shown that $\mathrm{Ag}$ and $\mathrm{Cu}$ nanoparticles agglomerate and transform into $\mathrm{AgCl}$ and $\mathrm{CuCl}_{2}$. 


\section{Acknowledgement}

I.I. Kamińska and A. Śrębowata would like to thank the Institute of Physical Chemistry PAS in Warsaw for the financial support.

\section{References}

1. M.A. Kean, ChemCatChem, 3 (2011), 800-821.

2. D. Comandella, S. Woszidlo, A. Georgi, F.D. Kopinke, K. Mackenzie, Appl. Catal. B 186 ( 2016) 204-211.

3. M.Martin-Martinez, L.M.Gómez-Sainero, J.Bedia, A.Arevalo-Bastante, J.J.Rodriguez, Appl. Catal. B 184 (2016) 55-63.

4. M. Bonarowska, Z. Karpiński, R. Kosydar, T. Szumełda, A. Drelinkiewicz, C. R. Chim. 18 (2015) 1143-1151.

5. R. Baran, I.I. Kamińska, A. Śrębowata, S. Dzwigaj, Micropor. Mesopor. Mater. 169 (2013) 120-127.

6. A. Śrębowata, R. Baran, D. Łomot, D. Lisovytskiy, T. Onfroy, S. Dzwigaj, Appl. Catal. B 147 (2014) 208-220.

7. A. Śrębowata, R. Baran, S. Casale, I.I. Kamińska, D. Łomot, D. Lisovytskiy, S. Dzwigaj, Appl. Catal. B152-153 (2014) 317-327.

8. A. Śrębowata, I. Zielińska, R. Baran, G. Słowik, S. Dzwigaj, Catal. Commun. 69 (2015) $154-160$.

9. IUPAC Recommendations, Pure Appl. Chem., 1985, 57, 603-619

10. IUPAC Recommendations, Pure Appl. Chem., 1994, 66, 1739-1758

11. A. Śrębowata, R. Baran, G. Słowik, D. Lisovytskiy, S. Dzwigaj, Appl. Catal. B 199 (2016) 514-522. 
12. D. Sun, Y. Yamada, S. Sato, Appl. Catal.A 475 (2014) 63-68.

13. X. Zheng, Q. Zhang, Y. Guo, W. Zhan, Y. Guo, Y. Wang, G. Lu, J. Mol. Catal. 357 (2012) 106-111.

14. N. Popovych, P. Kyriienko, S. Soloviev, S. Orlyk, S. Dzwigaj, Micropor. Mesopor. Mater. 203 (2015) 163-169.

15. D. Chen, Z. Qu, S. Shen, X. Li, Y. Shi, Y. Wang, Q. Fu, J. Wu, Catal. Today 175 (2011) 338-345.

16. M.A. Álvarez-Montero, L.M. Gómez-Sainero, A. Mayoral, I. Diaz, R.T. Baker, J.J. Rodriguez, J. Catal. 279 (2011) 389-396.

17. S. Ordóñez, F. V. Diez, H. Sastre, Appl. Catal. B 31 (2001) 113-122.

18. K. Foger, D. Hay, H. Jaeger, J. Catal. 96 (1985) 154-169.

19. S.C. Fung, J.H. Sinfelt, J. Catal. 103 (1987) 220-223.

20. M. Martin-Martinez, L.M. Gómez-Sainero, M.A. Alvarez-Montero, J. Bedia, J.J. Rodriguez, Appl. Catal. 132-133 (2013) 256-265.

21. D. Zhang, Y. Wei, L. Xu, F. Chang, Z. Liu, S. Meng, B.-L. Su, Z. Liu, Micropor. Mesopor. Mater. 116 (2008) 684-692.

22. D. Esquivel, A. J. Cruz-Cabeza, C. Jimenez-Sanchidrian, F.J. Romero-Salguero, Micropor. Mesopor. Mater. 142 (2011) 672-679.

23. S. Dzwigaj, J. Janas, J. Mizera, J. Gurgul, R.P. Socha, M. Che, Catal. Lett. 126 (2008) $36-42$.

24. J. Janas, J. Gurgul, R.P. Socha, S. Dzwigaj, Appl. Catal. B 91 (2009) 217-224.

25. Q. Yea, L. Wanga, R.T. Yanga, Appl. Catal. A 427- 428 (2012) 24-34.

26. X. Li, X. Zhang, L. Lei, Separ PurifTechn-64 (2009) 326-331.

27. M. Zahmakıran, F. Durap, S. Ozkar, Int. J. Hydrogen Energy 35 (2010) 187-197. 
Table 1. Specific surfaces area, pore volume and weighted average pore size determined from the nitrogen adsorption-desorption isotherms of calcined zeolite catalysts.

\begin{tabular}{|l|c|c|c|}
\hline \multicolumn{1}{|c|}{ Sample } & $\begin{array}{c}\text { Specific surface area } \\
\left(\mathrm{m}^{2} \mathrm{~g}^{-1}\right)\end{array}$ & $\begin{array}{c}\text { Pore volume } \\
\left(\mathrm{cm}^{3} \mathrm{~g}^{-1}\right)\end{array}$ & $\begin{array}{c}\text { Weighted } \\
\text { average pore } \\
\text { size } \\
(\mathrm{nm})\end{array}$ \\
\hline $\mathrm{C}-\mathrm{Ag}_{2.0} \mathrm{Cu}_{2.0} \mathrm{SiBeta}$ & 333 & 0.14 & 1.53 \\
\hline $\mathrm{C}-\mathrm{Ag}_{2.0} \mathrm{Cu}_{2.0} \mathrm{HAlBeta}$ & 303 & 0.13 & 1.49 \\
\hline
\end{tabular}

${ }^{\mathrm{a}}$ calculated from BET isotherms

${ }^{\mathrm{b}}$ calculated from Horvath-Kawazoe function 


\section{Figure captions}

Figure 1. Adsorption and desorption isotherms of $\mathrm{N}_{2}$ at $77 \mathrm{~K}$ for calcined $\mathrm{C}-\mathrm{Ag}_{2.0} \mathrm{Cu}_{2.0} \mathrm{SiBeta}$ and $\mathrm{C}-\mathrm{Ag}_{2.0} \mathrm{Cu}_{2.0} \mathrm{HAlBeta}$. Empty symbols: adsorption; filled symbols: desorption.

Figure 2. TPR patterns of $\mathrm{C}-\mathrm{Ag}_{2.0} \mathrm{Cu}_{2.0} \mathrm{SiBeta}$ and $\mathrm{CAg} \mathrm{g}_{2.0} \mathrm{Cu}_{2.0} \mathrm{HAlBEA} \mathrm{C}-$ $\mathrm{Ag}_{2.0} \mathrm{Cu}_{2.0} \mathrm{HAlBeta}$.

Figure 3. Time-on-stream behavior in hydrodechlorination of 1,2-DCE on red-C$\mathrm{Ag}_{2.0} \mathrm{Cu}_{2.0} \mathrm{SiBeta}$ and red-C- $\mathrm{Ag}_{2.0} \mathrm{Cu}_{2.0} \mathrm{HAlBeta}$ catalysts at $523 \mathrm{~K}$ : overall conversion.

Figure 4. Time-on-stream behavior in hydrodechlorination of 1,2-DCE on red-C$\mathrm{Ag}_{2.0} \mathrm{Cu}_{2.0} \mathrm{SiBeta}$ and red-C- $\mathrm{Ag}_{2.0} \mathrm{Cu}_{2.0} \mathrm{HAlBeta}$ catalysts at $523 \mathrm{~K}$ : ethylene selectivity.

Figure 5. Time-on-stream behavior in hydrodechlorination of 1,2-DCE on red-C$\mathrm{Ag}_{2.0} \mathrm{Cu}_{2.0} \mathrm{SiBeta}$ and red-C- $\mathrm{Ag}_{2.0} \mathrm{Cu}_{2.0} \mathrm{HAlBeta}$ catalysts at $523 \mathrm{~K}$ : vinyl chloride selectivity.

Figure 6. Bright field TEM micrographies of bimetallic red-C- $\mathrm{Ag}_{2.0} \mathrm{Cu}_{2.0} \mathrm{HAlBeta}$ (up) and spent-red-C- $\mathrm{Ag}_{2.0} \mathrm{Cu}_{2.0} \mathrm{HAlBeta}($ down) and XEDS spectra of representative nanoparticles.

Figure 7. Bright field TEM micrographies of bimetallic red-C- $\mathrm{Ag}_{2.0} \mathrm{Cu}_{2.0} \mathrm{SiBeta}$ (up) and spent-red-C- $\mathrm{Ag}_{2.0} \mathrm{Cu}_{2.0} \mathrm{SiBeta}(\mathrm{down})$ and XEDS spectra of representative nanoparticles

Figure 8. Correlation diagram for composition and size of nanoparticles for red-C$\mathrm{Ag}_{2.0} \mathrm{Cu}_{2.0} \mathrm{HAlBeta}\left(\mathrm{up}\right.$ ) and spent-red-C- $\mathrm{Ag}_{2.0} \mathrm{Cu}_{2.0} \mathrm{HAlBeta}$ (down).

Figure 9. Correlation diagram for composition and size of nanoparticles for red-C$\mathrm{Ag}_{2.0} \mathrm{Cu}_{2.0} \mathrm{SiBeta}$ (up) and spent-red-C- $\mathrm{Ag}_{2.0} \mathrm{Cu}_{2.0} \mathrm{SiBeta}$ (down).

Figure 10. XRD results for SiBeta, as prepared $\mathrm{Ag}_{2.0} \mathrm{Cu}_{2.0} \mathrm{SiBeta}$, red-C- $\mathrm{Ag}_{2.0} \mathrm{Cu}_{2.0} \mathrm{SiBeta}$ and spent-red-C- $\mathrm{Ag}_{2.0} \mathrm{Cu}_{2.0} \operatorname{SiBeta}\left(\mathrm{x}-\mathrm{Ag}(0)\right.$, circles $-\mathrm{AgCl}$, stars $\left.-\mathrm{CuCl}_{2}\right)$.

Figure 11. XRD results for HAlBeta, as prepared $\mathrm{Ag}_{2.0} \mathrm{Cu}_{2.0} \mathrm{HAlBeta}$, red-C$\mathrm{Ag}_{2.0} \mathrm{Cu}_{2.0} \mathrm{HAlBeta}$ and spent-red-C- $\mathrm{Ag}_{2.0} \mathrm{Cu}_{2.0} \mathrm{HAlBeta}(\mathrm{x}-\mathrm{Ag}(0)$, circles $-\mathrm{AgCl}$, stars $\mathrm{CuCl}_{2}$ ). 
Figure 12. TPH profiles for spent-red-C- $\mathrm{Ag}_{2.0} \mathrm{Cu}_{2.0} \mathrm{SiBeta}$ catalyst after hydrodechlorination of 1,2-DCE.

Figure 13. TPH profiles for spent-red-C- $\mathrm{Ag}_{2.0} \mathrm{Cu}_{2.0} \mathrm{HAlBeta}$ catalyst after hydrodechlorination of 1,2-DCE. 


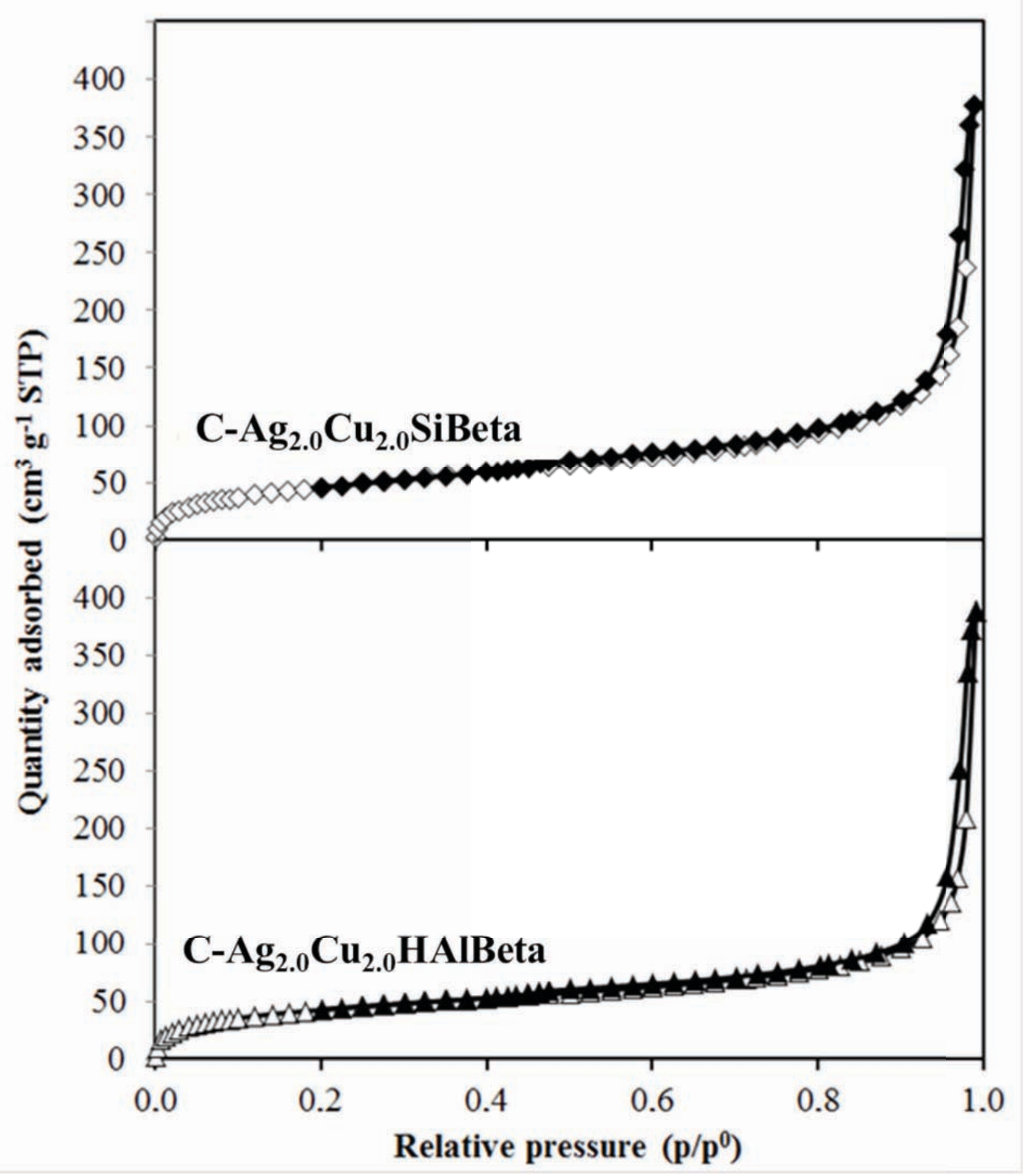

Figure 1 


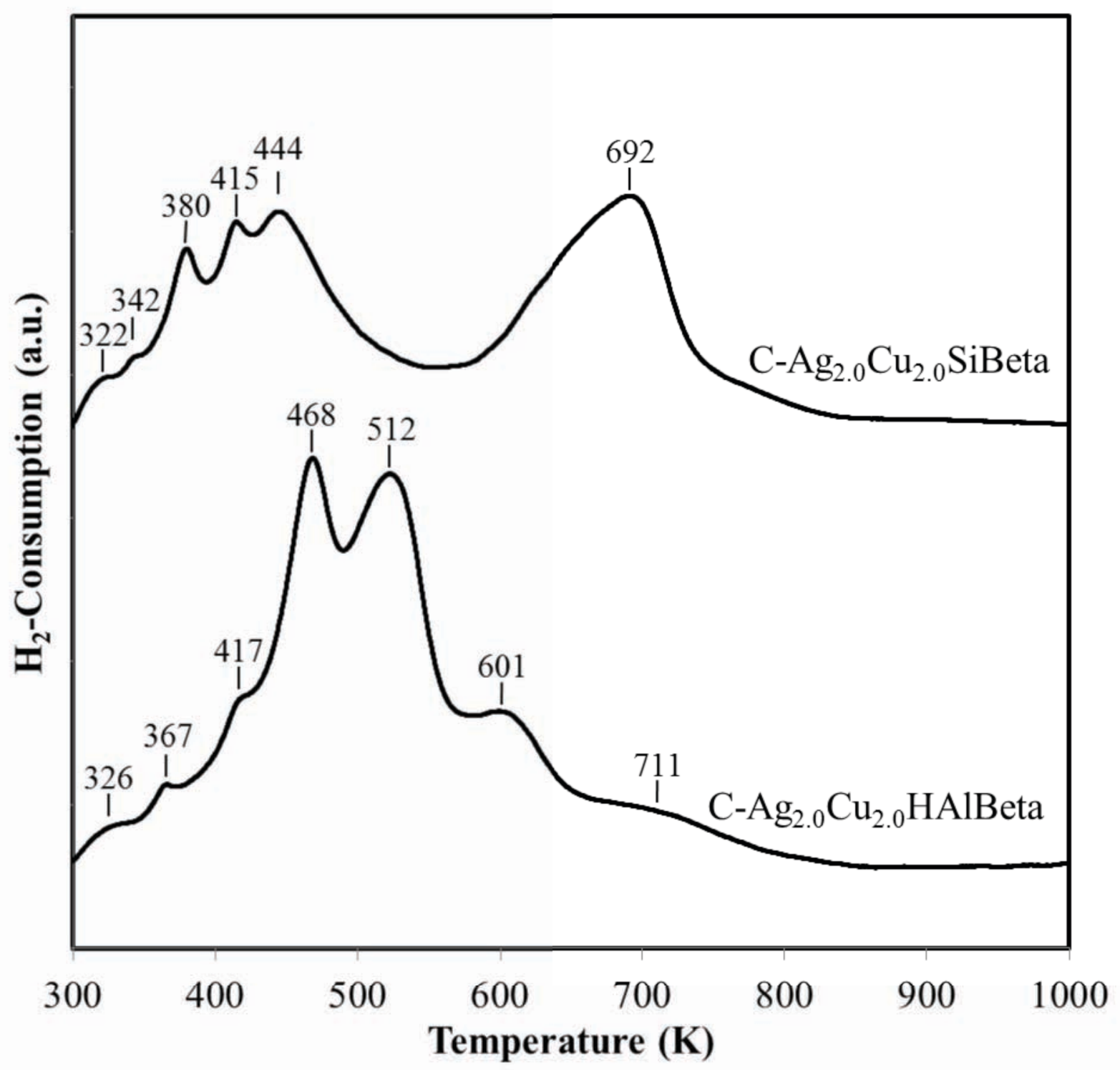

Figure 2 


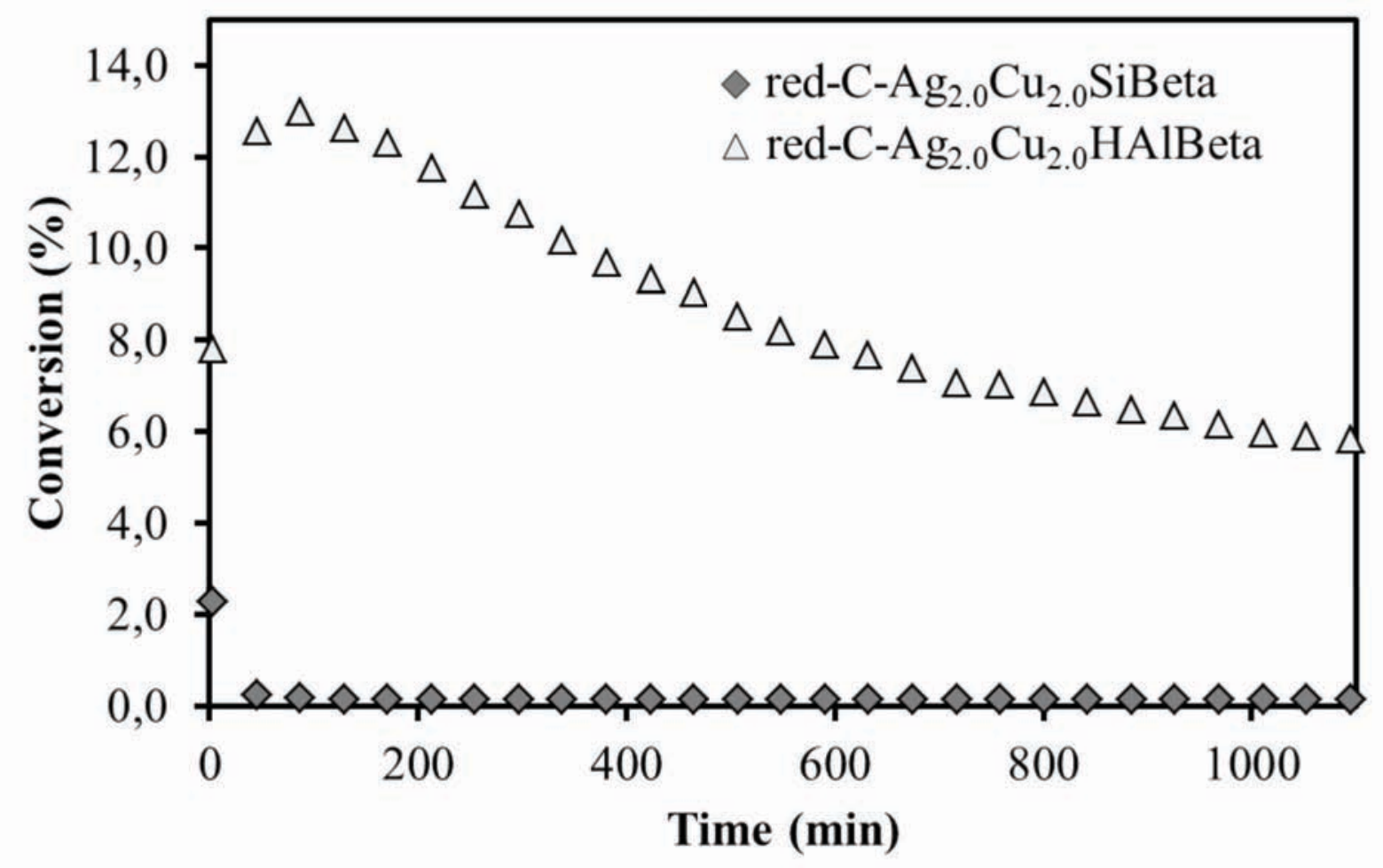

Figure 3 


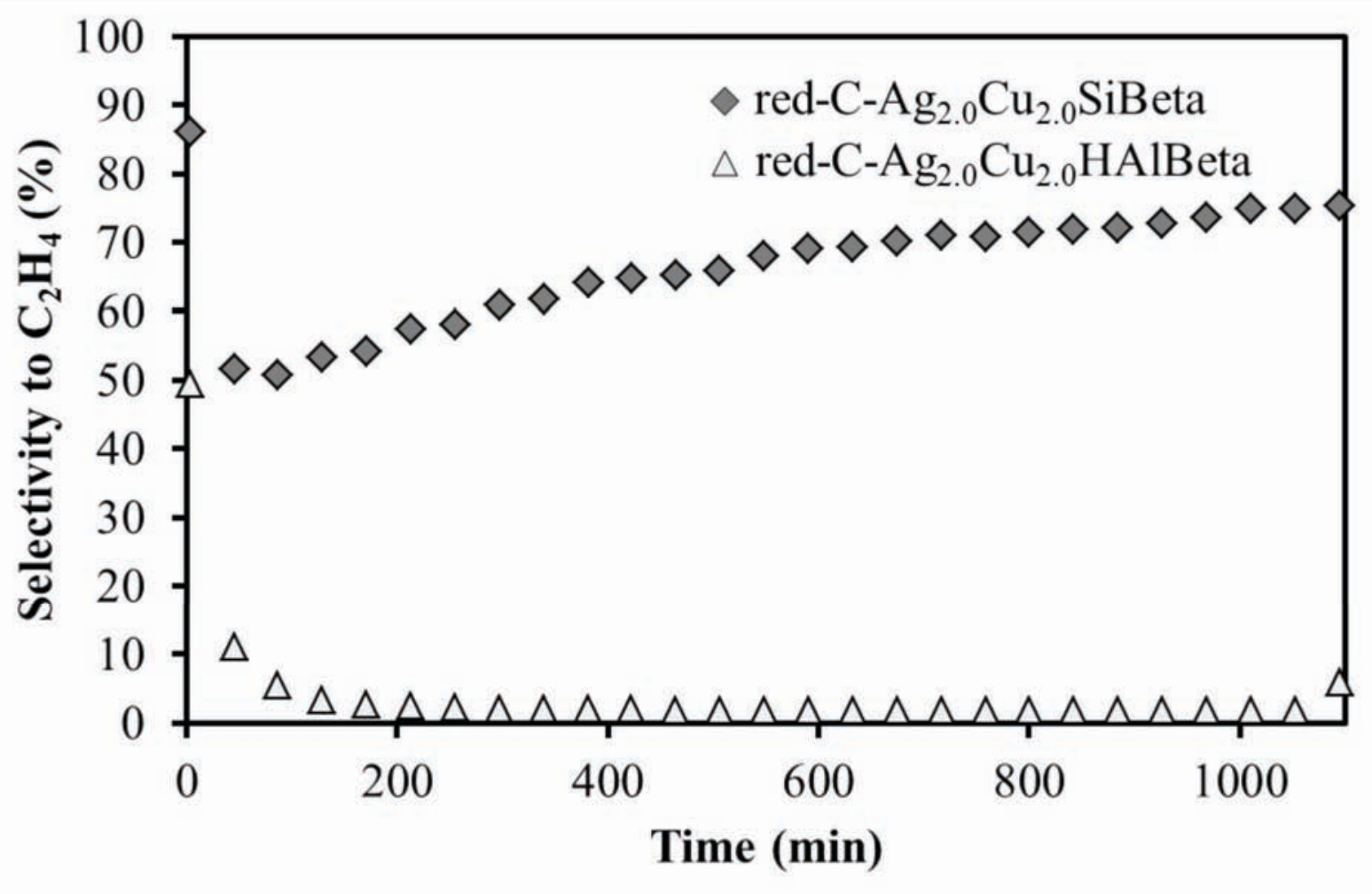

Figure 4 


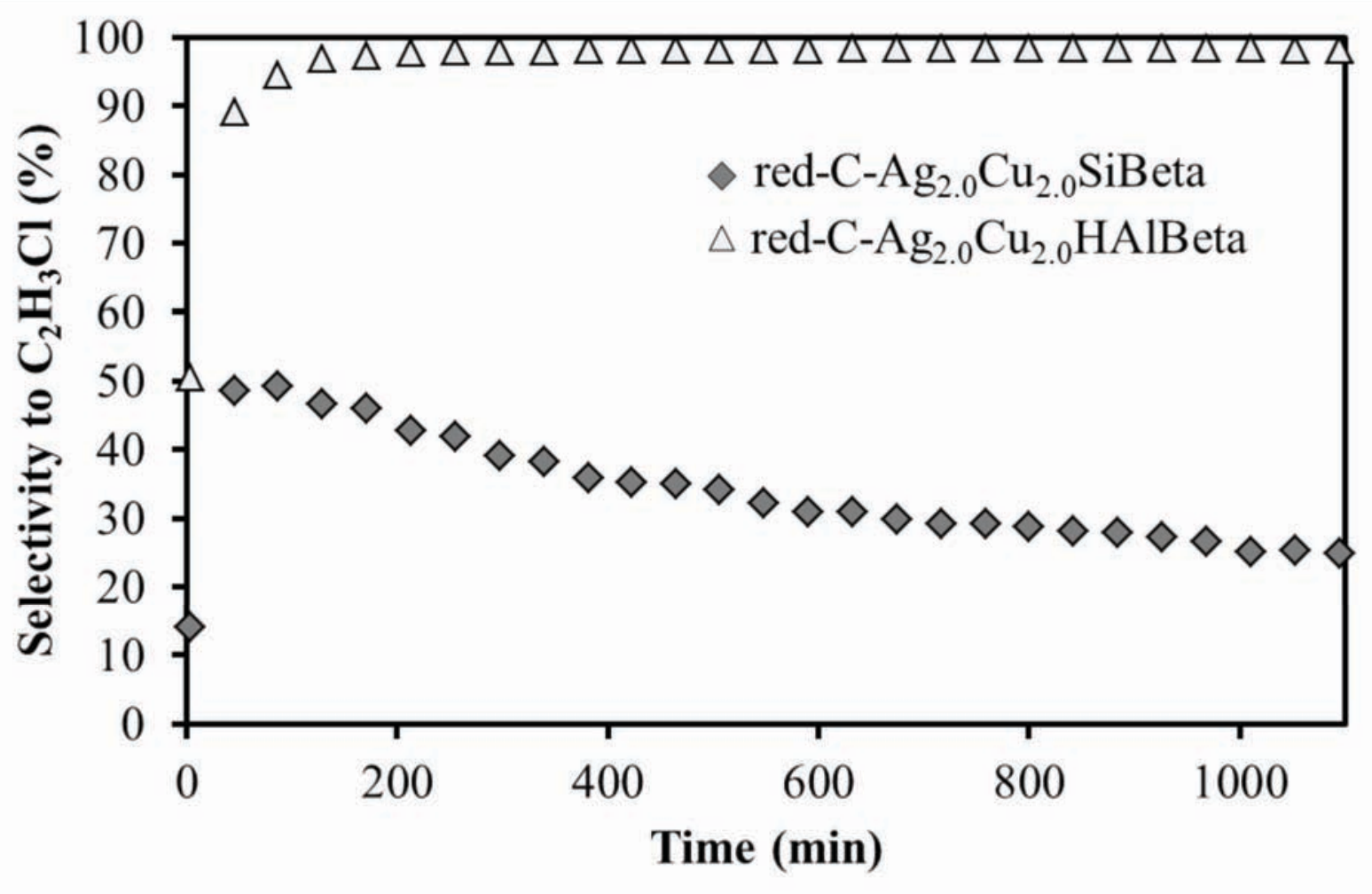

Figure 5 

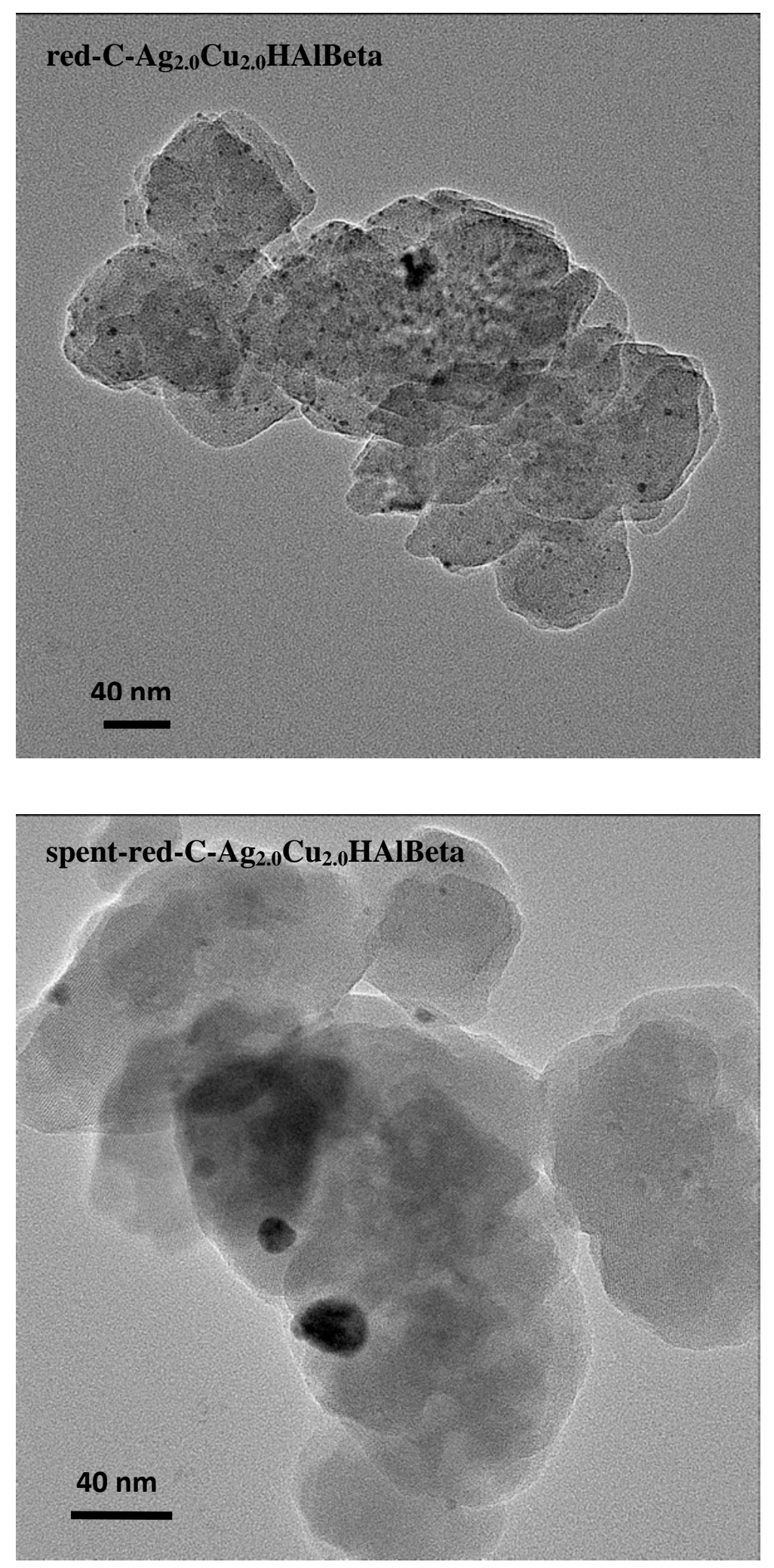

Figure 6 

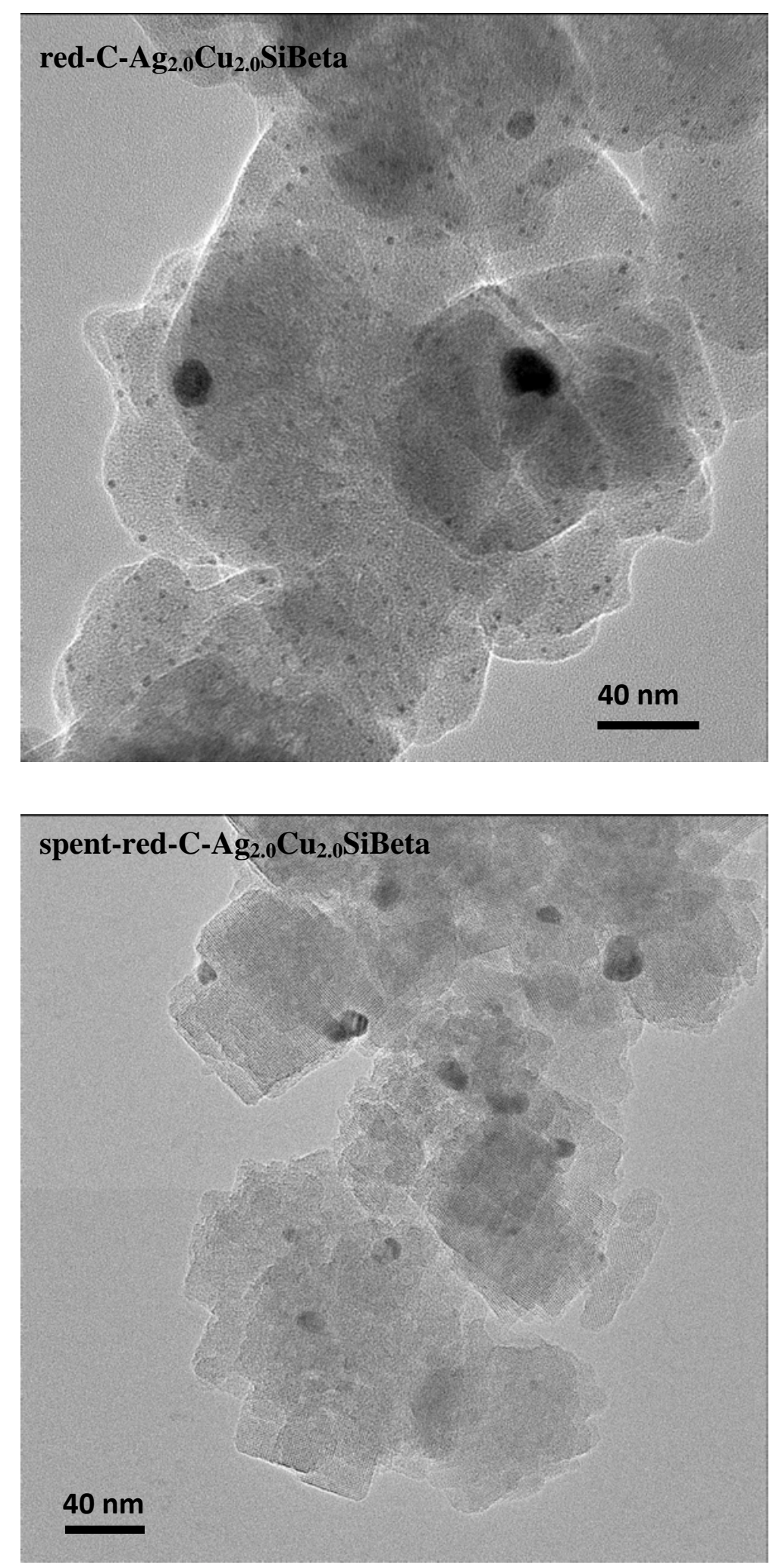

Figure 7 


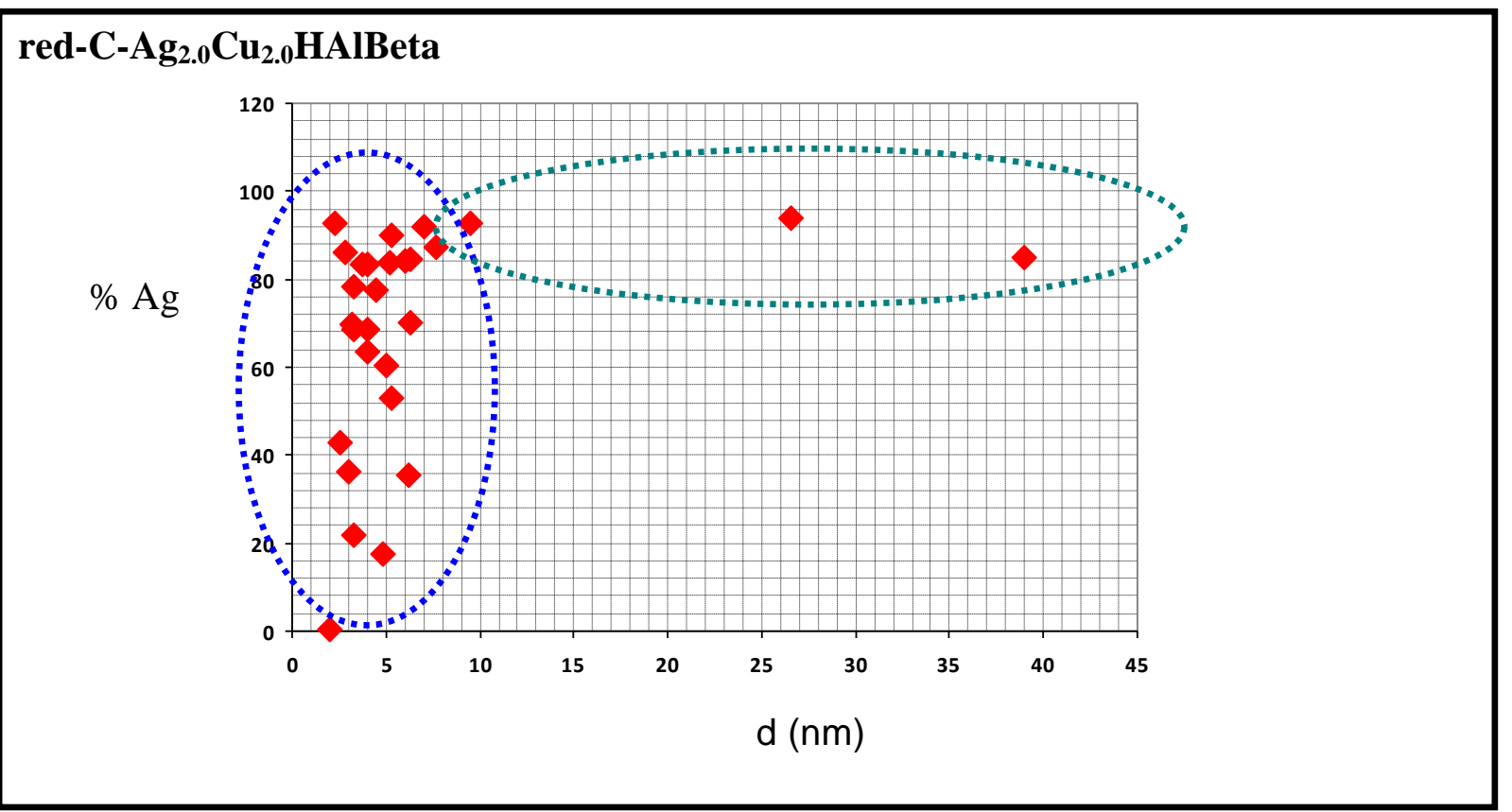

spent-red-C-Ag..0 $\mathrm{Cu}_{2.0} \mathrm{HAIBeta}$

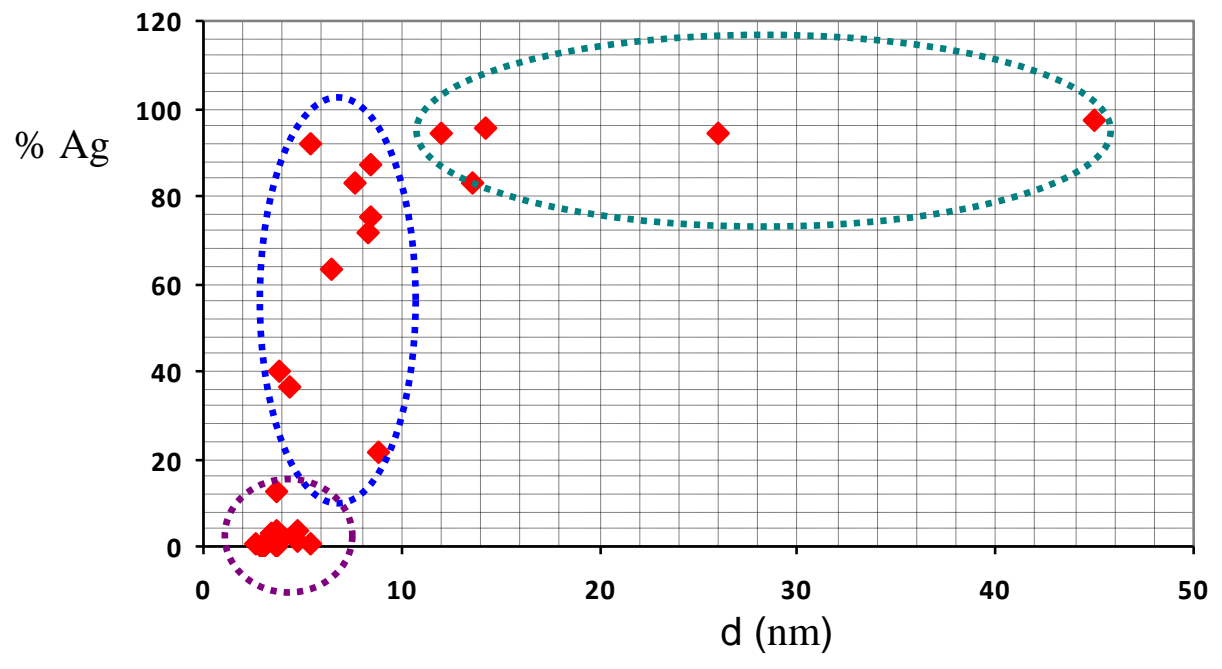

Figure 8 


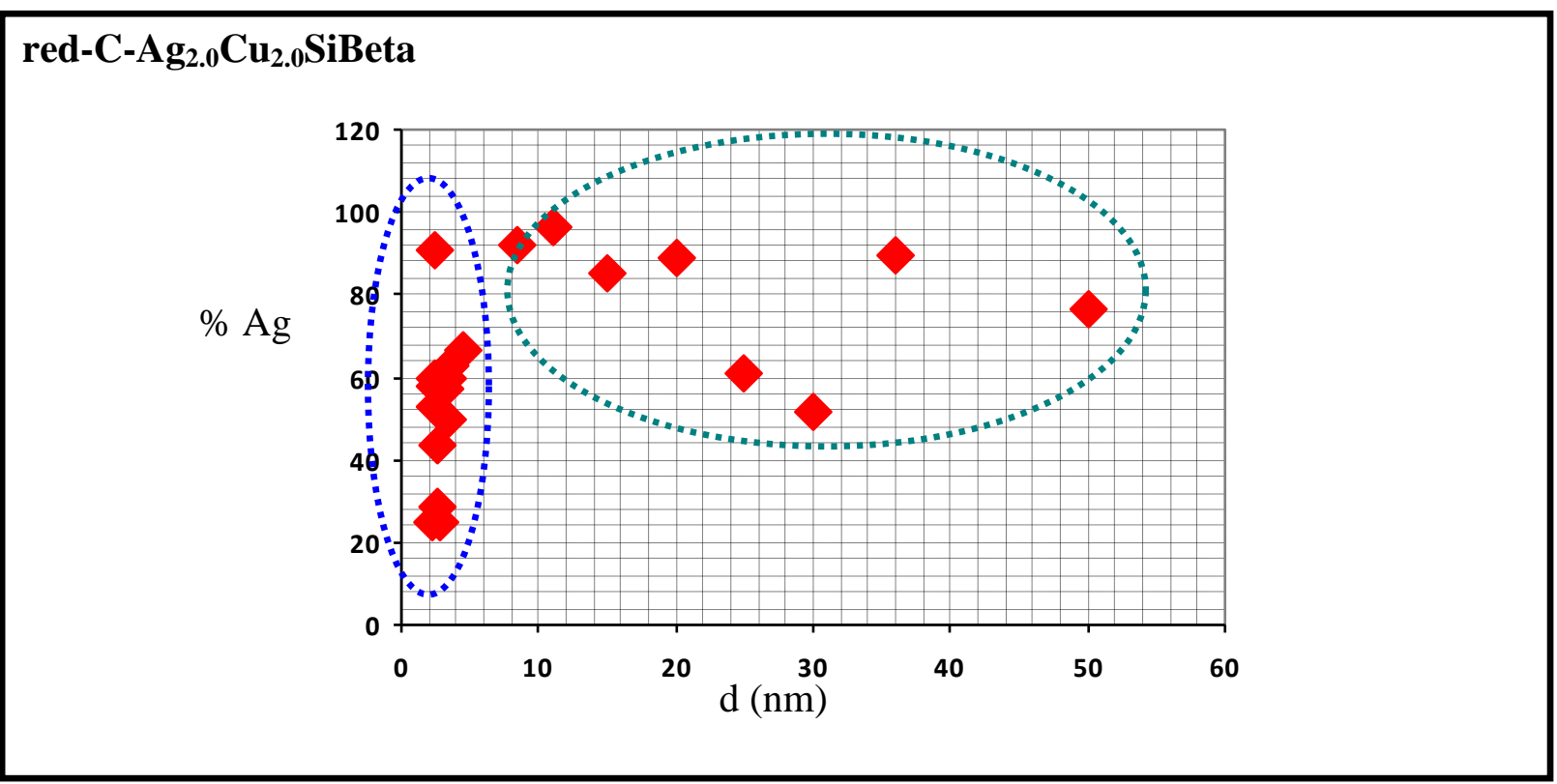

spent-red-C-Ag $\mathrm{Ag}_{2.0} \mathrm{Cu}_{2.0} \mathrm{SiBeta}$

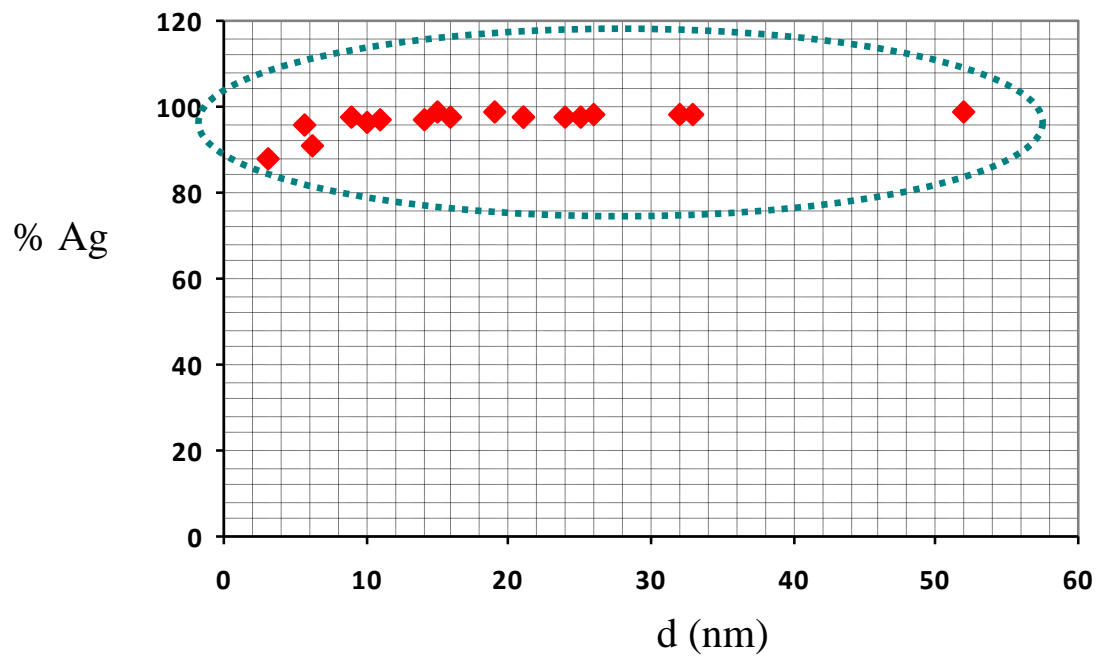

Figure 9 


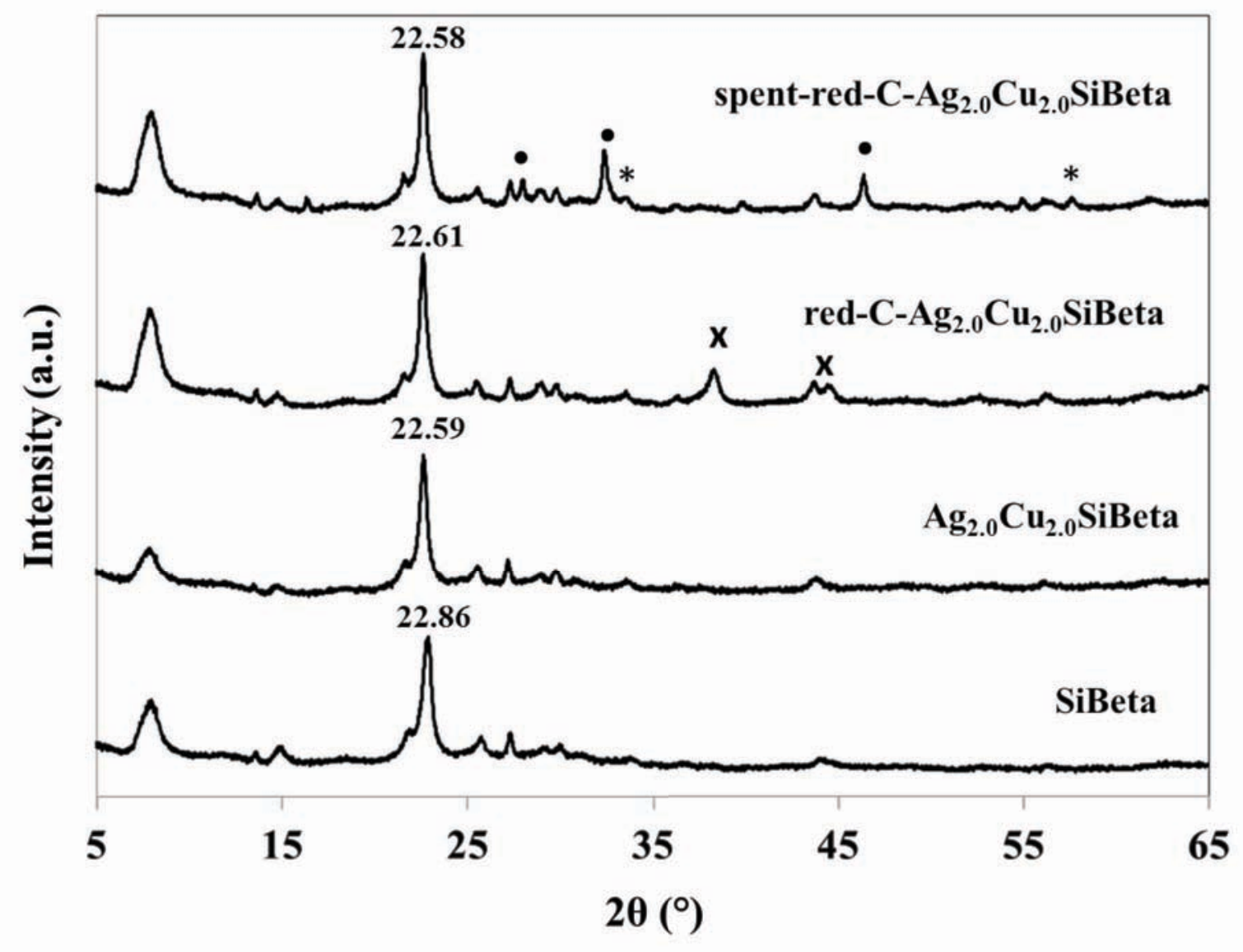

Figure 10 


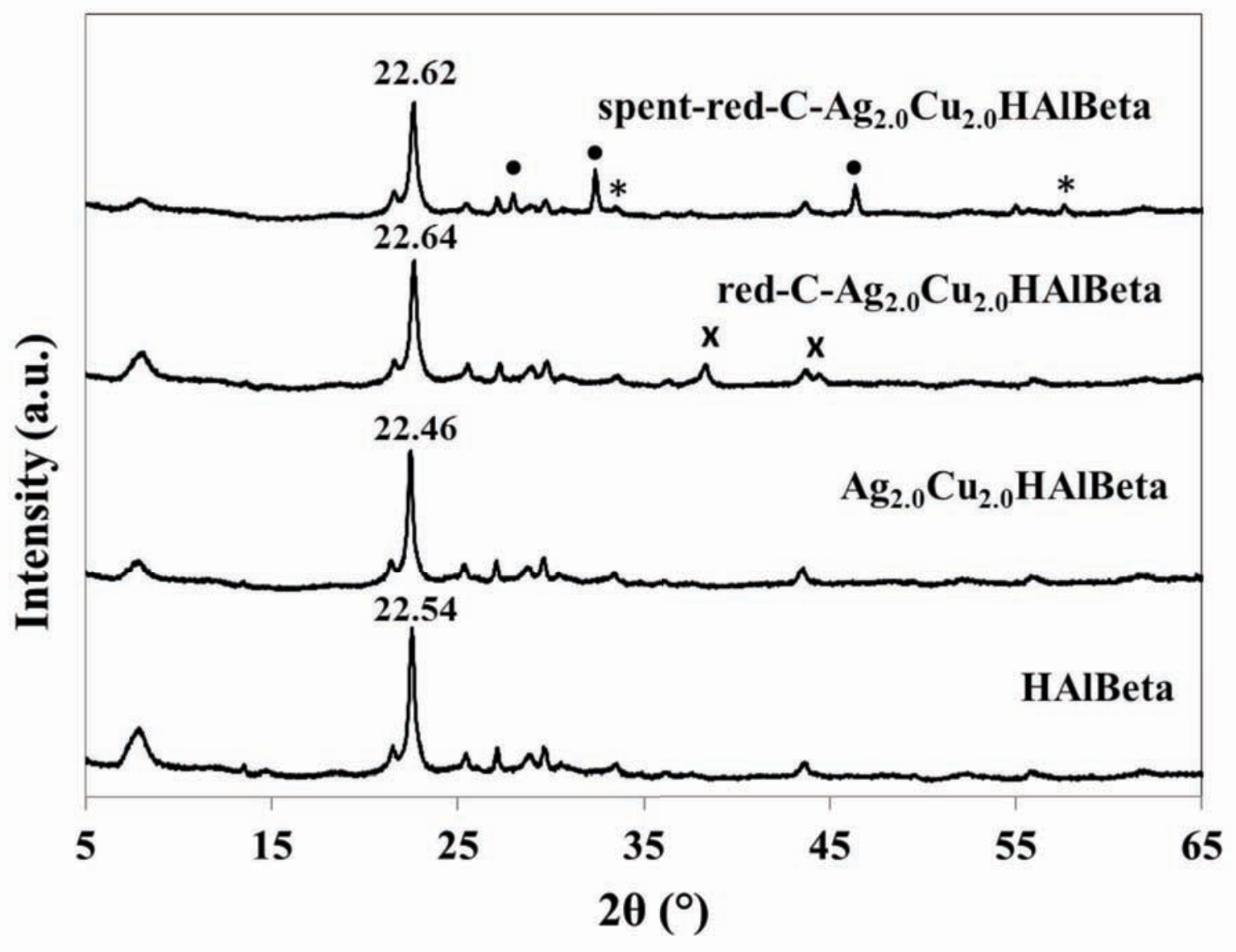

Figure 11 


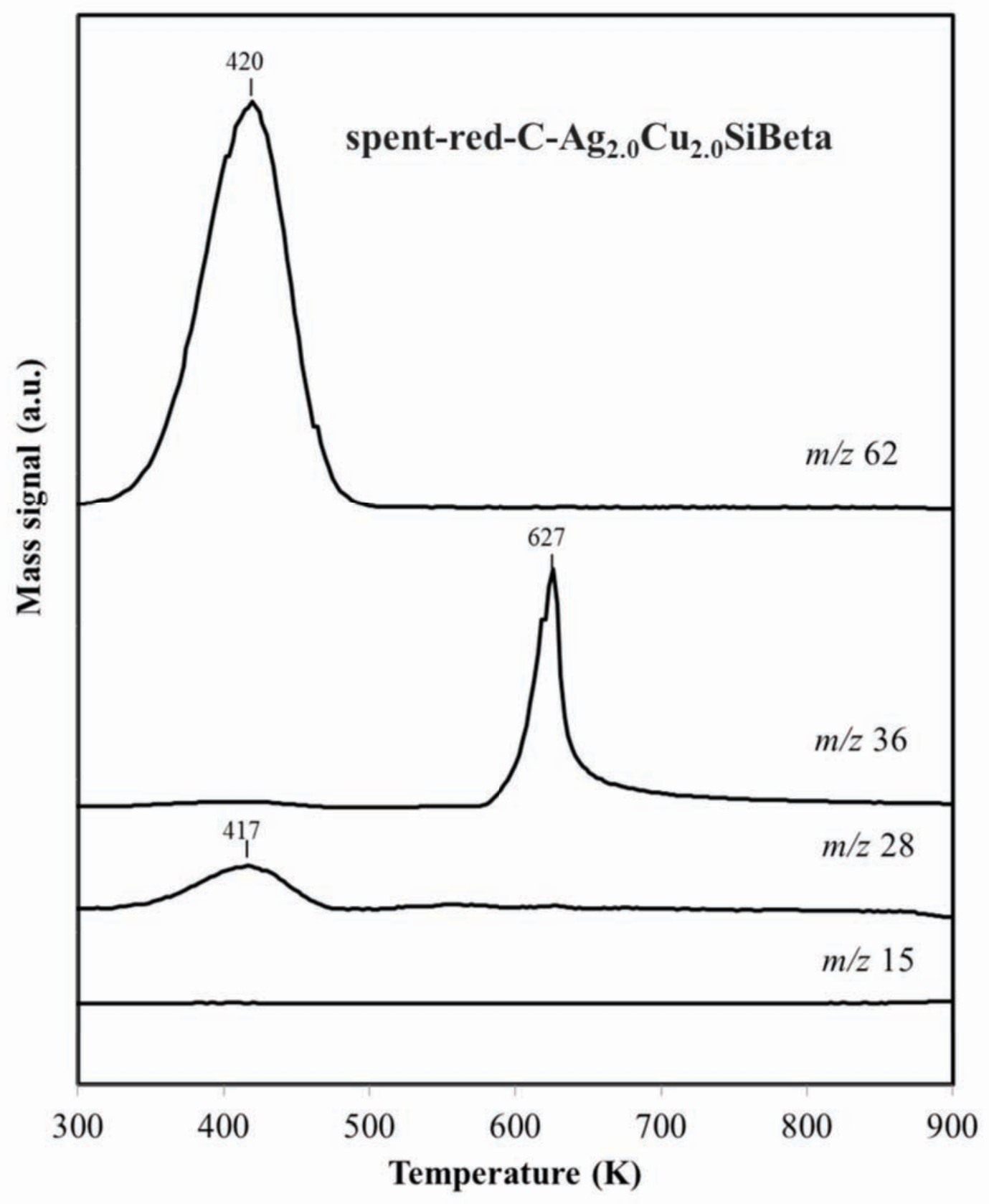

Figure 12 


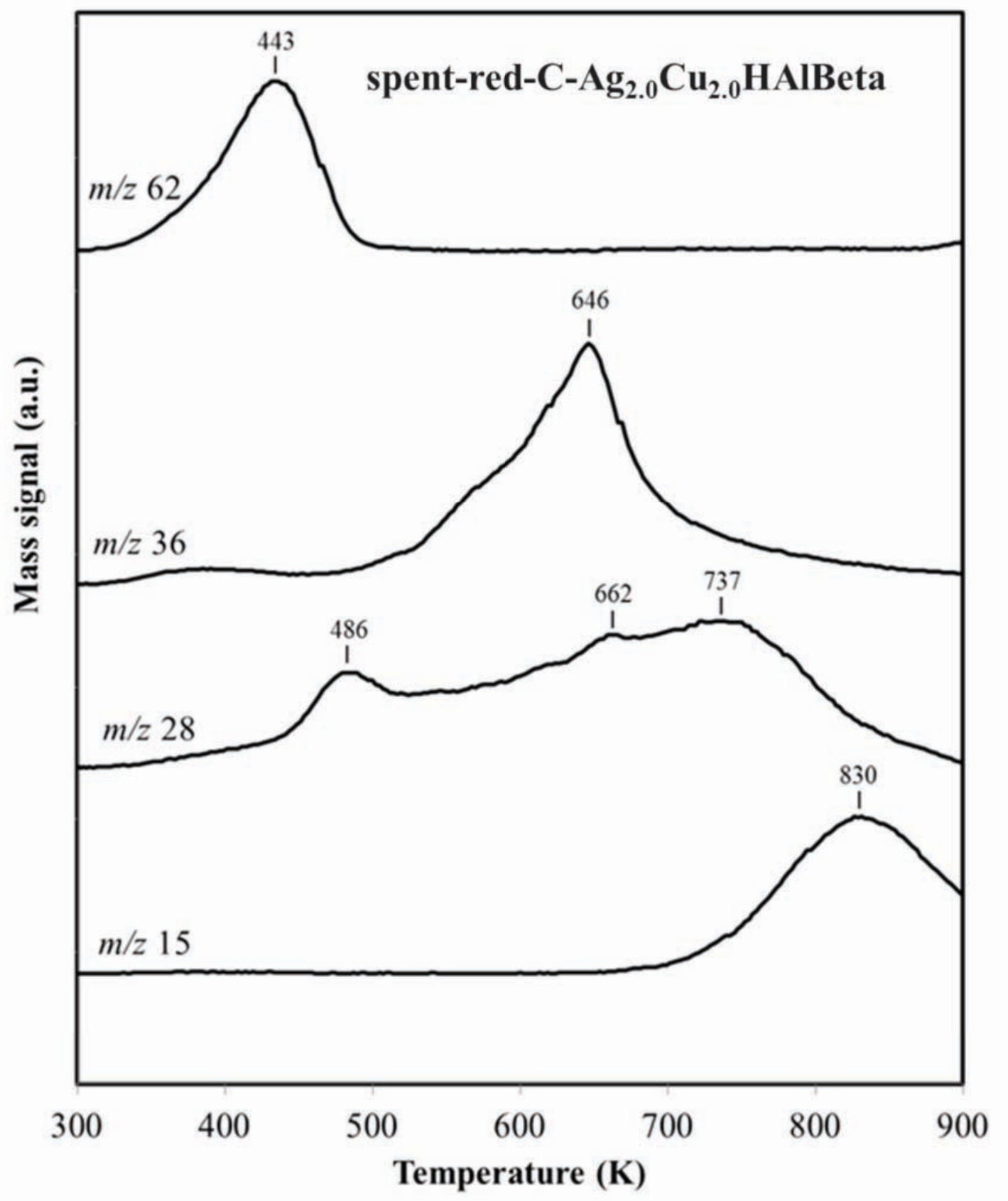

Figure 13 
Highlights:

- Two-step postsynthesis method leads to formation small $\mathrm{Ag}$ and $\mathrm{Cu}$ nanoparticles.

- Vinyl chloride and/or ethylene are the main products of HDC of 1,2-dichloroethane.

- During $\mathrm{HDC} \mathrm{Ag}$ and $\mathrm{Cu}$ nanoparticles agglomerate and transform into $\mathrm{AgCl}$ and $\mathrm{CuCl}_{2}$. 